\title{
PV Module Design for Recycling Guidelines 2021
}




\section{What is IEA PVPS TCP?}

The International Energy Agency (IEA), founded in 1974, is an autonomous body within the framework of the Organization for Economic Cooperation and Development (OECD). The Technology Collaboration Programme (TCP) was created with a belief that the future of energy security and sustainability starts with global collaboration. The programme is made up of 6.000 experts across government, academia, and industry dedicated to advancing common research and the applic ation of specific energy technologies.

The IEA Photovoltaic Power Systems Programme (IEA PVPS) is one of the TCP's within the IEA and was established in 1993. The mission of the programme is to "enhance the international collaborative efforts which facilitate the role of photovoltaic solar energy as a cornerstone in the transition to sustainable energy systems." In order to achieve this, the Programme's participants have undertaken a variety of joint research projects in PV power systems applications. The overall programme is headed by an Executive Committee, comprised of one delegate from each country or organisation member, which designates distinct 'Tasks,' that may be research projects or activity areas.

The IEA PVPS participating countries are Australia, Austria, Belgium, Canada, Chile, China, Denmark, Finland, France, Germany, Israel, Italy, Japan, Korea, Malaysia, Mexico, Morocco, the Netherlands, Norway, Portugal, South Africa, Spain, Sweden, Switzerland, Thailand, Turkey, and the United States of America. The European Commission, Solar Power Europe, the Smart Electric Power Alliance (SEPA), the Solar Energy Industries Association and the Cop-per Alliance are also members.

Visit us at: www.iea-pvps.org

\section{What is IEA PVPS Task 12?}

Task 12 aims at fostering international collaboration in safety and sustainability that are crucial for assuring that PV grows to levels enabling it to make a major contribution to the needs of the member countries and the world. The overall objectives of Task 12 are to 1. Quantify the environmental profile of PV in comparison to other energy technologies; 2 . Investigate end of life management options for PV systems as deployment increases and older systems are decommissioned; 3. Define and address environmental health \& safety and other sustainability issues that are important for market growth. The first objective of this task is well served by life cycle assessments (LCAs) that describe the energy-, material-, and emission-flows in all the stages of the life of PV. The second objective is addressed through analysis of including recycling and other circular economy pathways, like designing new PV systems for increased circularity as is the subject of this report. For the third objective, Task 12 develops methods to quantify risks and opportunities on sustainability topics of stakeholder interest. Task 12 is operated jointly by the National Renewable Energy Laboratory (NREL) and University of New South Wales (UNSW). Support from the United States Department of Energy (DOE) and UNSW are gratefully acknowledged. Further information on the activities and results of the Task can be found at: https://iea-pvps.org/researchtasks/pv-sustainability/.

\section{Authors}

> Main Content: Jose I. Bilbao, Garvin Heath, Alex Norgren, Marina M. Lunardi, Alberta Carpenter, Richard Corkish

\section{Editor: Jarett Zuboy}

\section{DISCLAIMER}

The IEA PVPS TCP is organised under the auspices of the International Energy Agency (IEA) but is functionally and legally autonomous. Views, findings and publications of the IEA PVPS TCP do not necessarily represent the views or policies of the IEA Secretariat or its individual member countries

\section{COVER PICTURE}

Ground mounted PV installation in Sayaton, Spain. Copyright G. Neubourg 


\title{
PV Module Design for Recycling Guidelines
}

\author{
IEA PVPS \\ Task 12: PV Sustainability
}

\author{
Report IEA-PVPS T12-23:2021 \\ October - 2021
}

ISBN 978-3-907281-27-7

\section{Operating Agents:}

Garvin Heath, National Renewable Energy Laboratory, Golden, CO, USA José Bilbao, University of New South Wales, Sydney, Australia

\author{
Authors: \\ Jose I. Bilbao, Garvin Heath, Alex Norgren, Marina M. Lunardi, Alberta \\ Carpenter, Richard Corkish
}

Citation: Jose I. Bilbao, Garvin Heath, Alex Norgren, Marina M. Lunardi, Alberta Carpenter, Richard Corkish, 2021, PV Module Design for Recycling, International Energy Agency (IEA) PVPS Task 12, Report T12-23:2021. ISBN 978-3-907281-27-7. 



\section{TABLE OF CONTENTS}

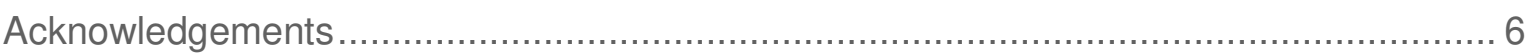

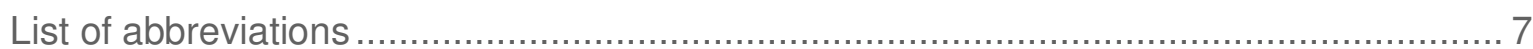

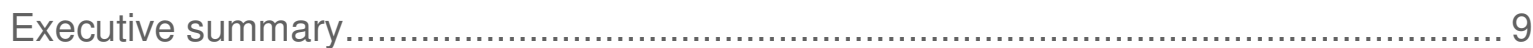

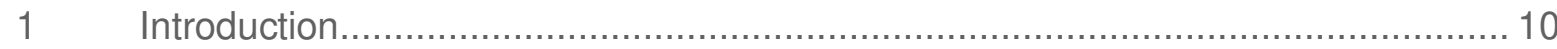

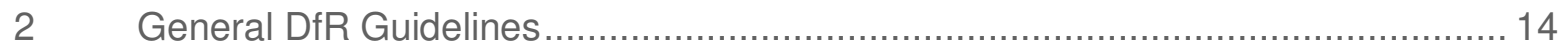

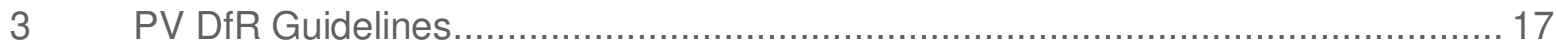

3.1 General and c-Si PV DfR Guidelines ............................................... 17

3.2 Thin Film PV ................................................................................. 25

3.3 Junction Boxes.............................................................................. 26

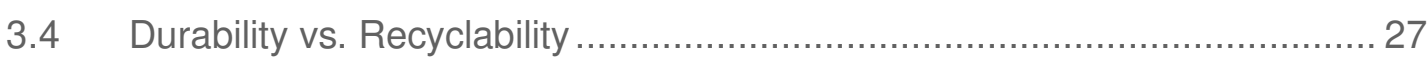

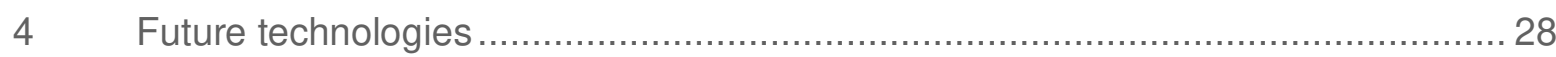

$4.1 \quad$ Pilot-Scale PV Pyrolysis Plant ......................................................... 28

$4.2 \quad$ Selective Chiselling of PV Layers ........................................................ 28

4.3 Improved Bi Handling in Cu Refining ............................................... 28

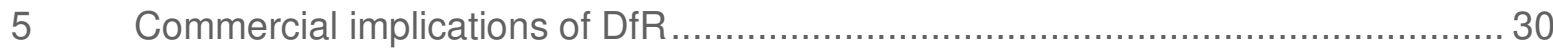

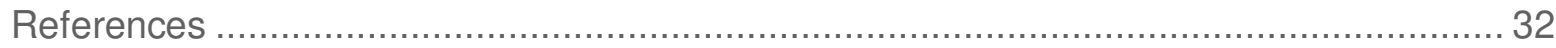




\section{ACKNOWLEDGEMENTS}

This paper received valuable contributions from IEA-PVPS Task 12 members and other international experts whom provided comments at various oral presentations of this material.

With regard to the content contributed by authors affiliated with the National Renewable Energy Laboratory (Garvin Heath, Alex Norgren, Alberta Carpenter), we wish to thank reviewers from the research, R\&D management, and industrial communities, including K. Podkaminer, J. Cresko, J. Engel-Cox, M. Kempe, R. Murray, D. Berry, A. Eberle, A. Burrell, M. Mann, S. Santhanagopalan, A. Wade, P. Sinha, F. Dross, I. Goudswaard, L. Mansfield, S. Jaako, M. O'Connor, S.M. Vettese, L. Gaines, S. Gillard, L. Tinker, J. Spangenberger, B. Polzin, K. McMahon, J. Cory, F. Della Rosa, K. Wambach, and M. Arbabzadeh for feedback on the earlier versions, and A. Hicks and J. Zuboy for graphics and editorial support. The National Renewable Energy Laboratory is operated by Alliance for Sustainable Energy, LLC for the U.S. Department of Energy (DOE) under Contract No. DE-AC36-08G028308. Funding was provided by U.S. Department of Energy Office of Energy Efficiency and Renewable Energy Office of Strategic Programs, Advanced Manufacturing Office and Solar Energy Technologies Office. The work was conducted under the Clean Energy Manufacturing Analysis Center (CEMAC, https://www.jisea.org/manufacturing.html) operated by the Joint Institute for Sustainable Energy Analysis (JISEA, www.jisea.org). The views expressed in the article do not necessarily represent the views of the DOE or the U.S. Government.

With regard to content contributed by the University of New South Wales-affiliated researchers, we wish to thank Renate Egan and funding provided by the Australian Centre for Advanced Photovoltaics (http://www.acap.net.au/).

The guidelines presented herein overlap substantially with those published in the Journal of Sustainable Metallurgy (volume 6, pages 761-774), in 2020 entitled, "Design for Recycling Principles Applicable to Selected Clean Energy Technologies: Crystalline-Silicon Photovoltaic Modules, Electric Vehicle Batteries, and Wind Turbine Blades." (https://doi.org/10.1007/s40831-020-00313-3). With the addition of a more substantial literature review and an additional guideline, this work supersedes the journal article with regard to its $\mathrm{PV}$ content. 


\section{LIST OF ABBREVIATIONS}

$\mathrm{Ag} \quad$ silver

Al aluminium

Al-BSF aluminium back surface field

$\mathrm{Bi} \quad$ bismuth

Cd cadmium

CdTe cadmium telluride

CIGS copper-indium-gallium-selenide

CIS copper indium selenide

c-Si crystalline silicon

$\mathrm{Cu} \quad$ copper

DEM double encapsulation module

DEMOC double encapsulation module with optical coupler

DfD design for disassembly

DfE design for the environment

DfR design for recycling

EOL end of life

EVA ethylene-vinyl acetate

F fluorine

FRELP Full Recovery End of Life Photovoltaic

$\mathrm{H}_{3} \mathrm{PO}_{4} \quad$ phosphoric acid

$\mathrm{HF} \quad$ hydrogen fluoride

$\mathrm{HNO}_{3} \quad$ nitric acid

IEA International Energy Agency

In indium

$\mathrm{KOH}$ potassium hydroxide

NEDO New Energy and Industrial Technology Development Organization

$\mathrm{Ni} \quad$ nickel

PaaS product-as-a-service

$\mathrm{Pb} \quad$ lead

PERC passivated emitter rear contact

PET polyethylene terephthalate 


$\begin{array}{ll}\text { PIB } & \text { polyisobutylene } \\ \text { PV } & \text { photovoltaic(s) } \\ \text { PVF } & \text { polyvinylfluoride } \\ \text { RFID } & \text { radio-frequency identification } \\ \mathrm{Se} & \text { selenium } \\ \mathrm{Si} & \text { silicon } \\ \mathrm{SiN}_{\mathrm{x}} & \text { silicon nitride } \\ \mathrm{Sn} & \text { tin } \\ \mathrm{Te} & \text { telluride } \\ \mathrm{TiO} & \\ \mathrm{USD} & \text { titanium dioxide } \\ \text { UV } & \text { U.S. dollar(s) } \\ \text { V } & \text { ultraviolet } \\ \text { VFRB } & \text { vanadium } \\ \text { WEEE } & \text { vanadium flow redox batteries } \\ \text { IEA } & \text { Waste Electrical and Electronic Equipment }\end{array}$




\section{EXECUTIVE SUMMARY}

The global growth of clean energy technology deployment will be inexorably followed by a parallel growth of end-of-life (EOL) products that bring both challenges and opportunities. Cumulatively, by 2050 , estimates project 78 million tonnes of raw materials embodied in the mass of EOL photovoltaic (PV) modules. Owing partly to concern that the projected growth of clean energy technologies could become constrained by availability of raw materials, despite ongoing dematerialization efforts, significant attention under the umbrella of circular economy has been brought to recycling these technologies at EOL. Yet PV has not been designed with recycling at EOL in mind, and it presents challenges to returning embodied raw materials back to use in new products through recycling. This study aims to inform future designs to improve recyclability through synthesis of prior published works augmented by novel recommendations that result in a set of general design for recycling (DfR) guidelines, with a subset specific to PV modules, as listed below.

\section{DfR General Guidelines}

1. Product requirements such as functionality, longevity, durability, reliability, and cost are critical; DfR should support or enhance these aspects but may result in trade-offs between recyclability and product performance and cost.

2. Material choice and the ability to liberate separate materials are critical to DfR outcomes.

3. Recycling outcomes can be enhanced by minimizing hazardous materials in products, or by recovering these materials completely via DfR.

4. Minimizing and managing hard-to-recycle materials can improve overall recycling yield.

5. Minimizing non-reversible adhesives or similar bonds, especially over whole surfaces and for dissimilar materials, can facilitate disassembly and material liberation.

6. Design for disassembly (DfD) can improve recyclability.

7. Estimating recyclability improvements and economic and environmental impacts due to DfR is important for continuous improvement, identification, and weighing of trade-offs and communicating value.

8. Using labels to identify recyclable and non-recyclable materials helps recyclers classify feedstocks; labelling standardization is important for uptake and utilization.

9. Designing products to use recycled materials promotes circular manufacturing.

DfR PV specific guidelines

1. Durable identification of module construction and composition could enable safer and more efficient recycling processes.

2. Backsheet composition has particularly important implications for recyclability.

3. Metal choices can have significant impacts on recycling processes and costs.

4. Minimizing encapsulant use or using reversible encapsulants can facilitate disassembly of PV modules.

5. Decreasing the number and complexity of module materials presents trade-offs related to recyclability and economics.

6. Using different sealants in the aluminium frame could enable module separation without component damage.

We further discuss how established trends in design of PV modules could affect recyclability. If adopted today, application of these DfR guidelines could help to mitigate tomorrow's resource scarcity, lower the barriers and cost for PV recycling, and enable a circular economy during the energy transition. 


\section{INTRODUCTION}

In the traditional linear economy, products are typically landfilled at end of life (EOL), and new products from virgin materials are manufactured to replace them. In contrast, a circular economy optimizes energy and material use over product life cycles by remanufacturing, refurbishing, repairing, reusing, and recycling EOL products, and/or extending initial product lifespans to increase the amount of useful service per product; when products can no longer be remanufactured, refurbished, repaired, or reused, recycling is the final circular option. Yet, many products comprise a complex mix of materials that are difficult to recover during recycling. One approach to bringing such products into the circular economy is to design them from the beginning with recycling in mind. Design for recycling (DfR) aims to facilitate economic recycling and maximise material recovery by designing products with a focus on increasing speed and ease of dismantling, improving recycling rate and purity of recovered materials, and reducing waste.

DfR focuses on manufacturing products that can be safely and economically recycled, using existing recycling technology and methods, when removed from service as well as replacing materials to have safer products for the environment and humans. However, in some cases, replacement of specific dangerous or rare components may not be feasible. In these cases, cooperation between manufacturers and recyclers is important for ensuring recycling and control of the resulting environmental risks [1].

DfR techniques have been applied for electronic devices since the early 1990s. In terms of environmental benefits, recycling not only reduces the amount of waste, but it can also lower the emissions produced and the energy inputs required to acquire and treat raw materials used [2].

Authors have proposed engineering practices that resemble DfR under a variety of other names and classifications [1, 3, 4, 5, 6]. The classification by Fiksel (Figure 1) identifies common pathways and methods between different design for the environment (DfE) strategies, where DfE is a heading that encompasses DfR, as seen in the figure.

DfR is optimally applied when looking beyond just the recycling process itself to the facets of the larger system (Figure 2). Recycling often consists of multiple processing stages. In ideal (but uncommon) situations, DfR can enable direct reuse of intact recovered components (denoted by the dashed blue line in Figure 2), which minimizes intermediate losses and overall recycling energy use. Reusing components usually requires fewer closed-loop life-cycle paths than recycling does, potentially providing a better economic value, particularly considering that existing $\mathrm{PV}$ recycling processes do not produce enough revenue to cover transport and processing costs [7].

Although multiple studies discuss DfR in some capacity, few studies attempt to identify specific strategies for implementing it $[5,8,9,10]$. Others provide broad DfR strategies and comment on DfR's relationship within broader sustainability practices [3, 6].

This report synthesizes DfR guidelines based on a review of published industrial and academic best practices, as well as consultation with experts in the field (listed in the Acknowledgements), with the addition of novel concepts introduced herein. The literature review - which was not exhaustive-focused on documents that explicitly identified DfR by its abbreviated or full name, with an emphasis on clean energy technologies. We also drew from sources recommended to us by experts and through other ad-hoc means, because not all studies that offered meaningful DfR insights contained use of the term DfR or its synonyms. 


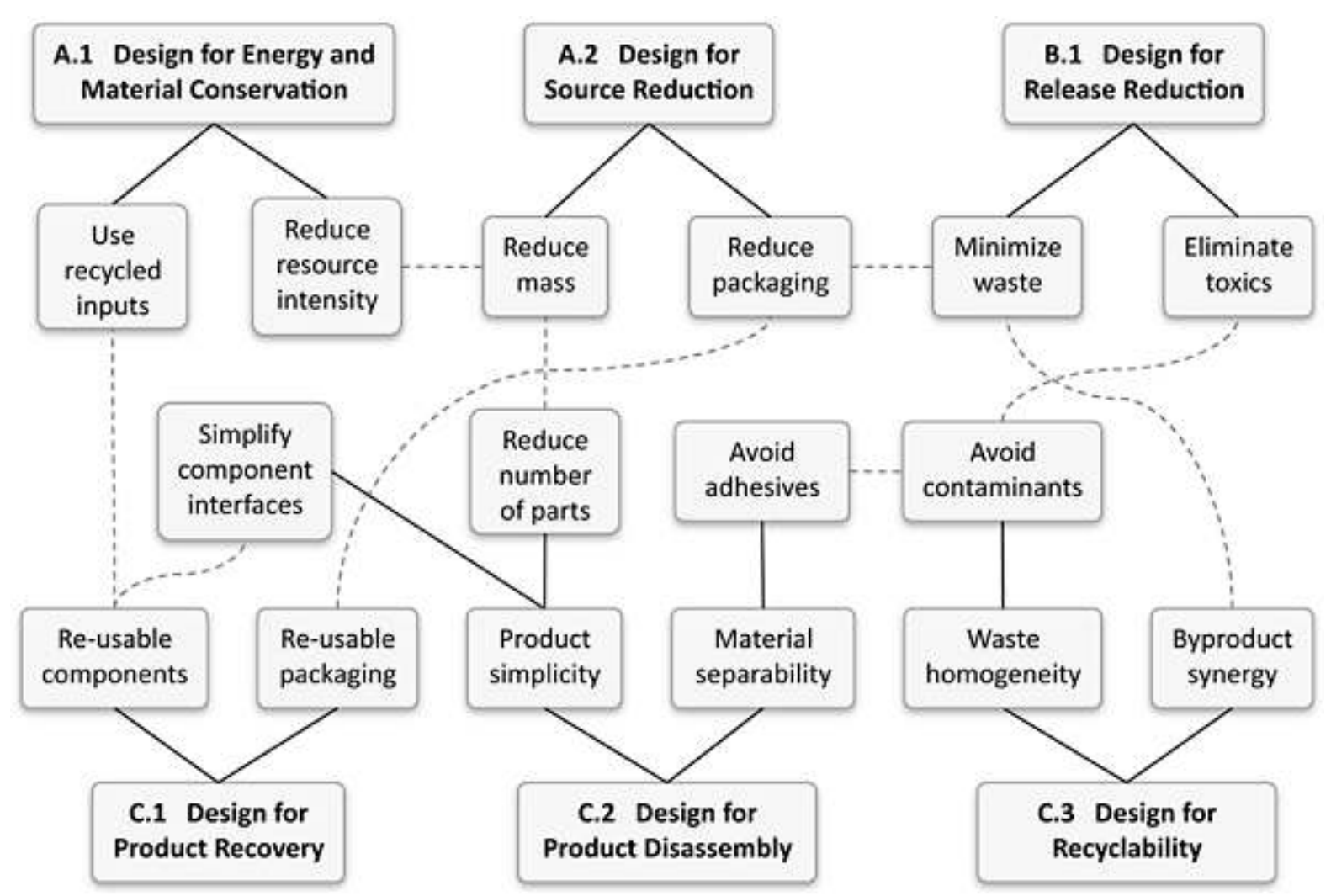

Figure 1. Fiksel's DfE guidelines fall under four categories: A) Design for Dematerialization, B) Design for Detoxification, C) Design for Revalorization, and D) Design for Capital Protection \& Renewal. Here, interrelationships among category A, B, and C DfE practices are reproduced from [3].

We focus particularly on the application of DfR to photovoltaics (PV) because of recent and projected PV growth (e.g., to fulfill renewable portfolio standards [11], 100\% renewable energy targets [12], and other initiatives, e.g., [13]) and to help ensure avoidance of waste management challenges in the future. Cumulatively, by 2050, estimates project 78 million tonnes of raw materials embodied in the mass of EOL PV modules [14].

Industrial-scale processes for recycling PV modules are still crude, consisting of mechanically shredding and crushing the modules and then chemically separating the more valuable materials. Current recycling technologies for modules based on crystalline silicon (c-Si), which represent approximately $90 \%$ of the global market [15], struggle to generate enough profits from the recovered materials to cover the costs of the recycling process [16, 17].

However, with improved recycling technologies, the recovered Si and other materials can be new feedstocks to the solar industry. Estimates suggest a possible revenue of US\$1112 /module, which enables a profitable recycling business for c-Si modules without government support [18]. Estimates for 2050 suggest that the cumulative recoverable value could exceed 15 billion US dollars (equivalent to the value of 2 billion modules, or $630 \mathrm{GW}$ ) [14]. Furthermore, recycling PV modules can ensure the long-term sustainability of the supply chain, increasing the recovery of energy and materials while reducing the greenhouse gas emissions and energy payback time related to PV modules [19]. 


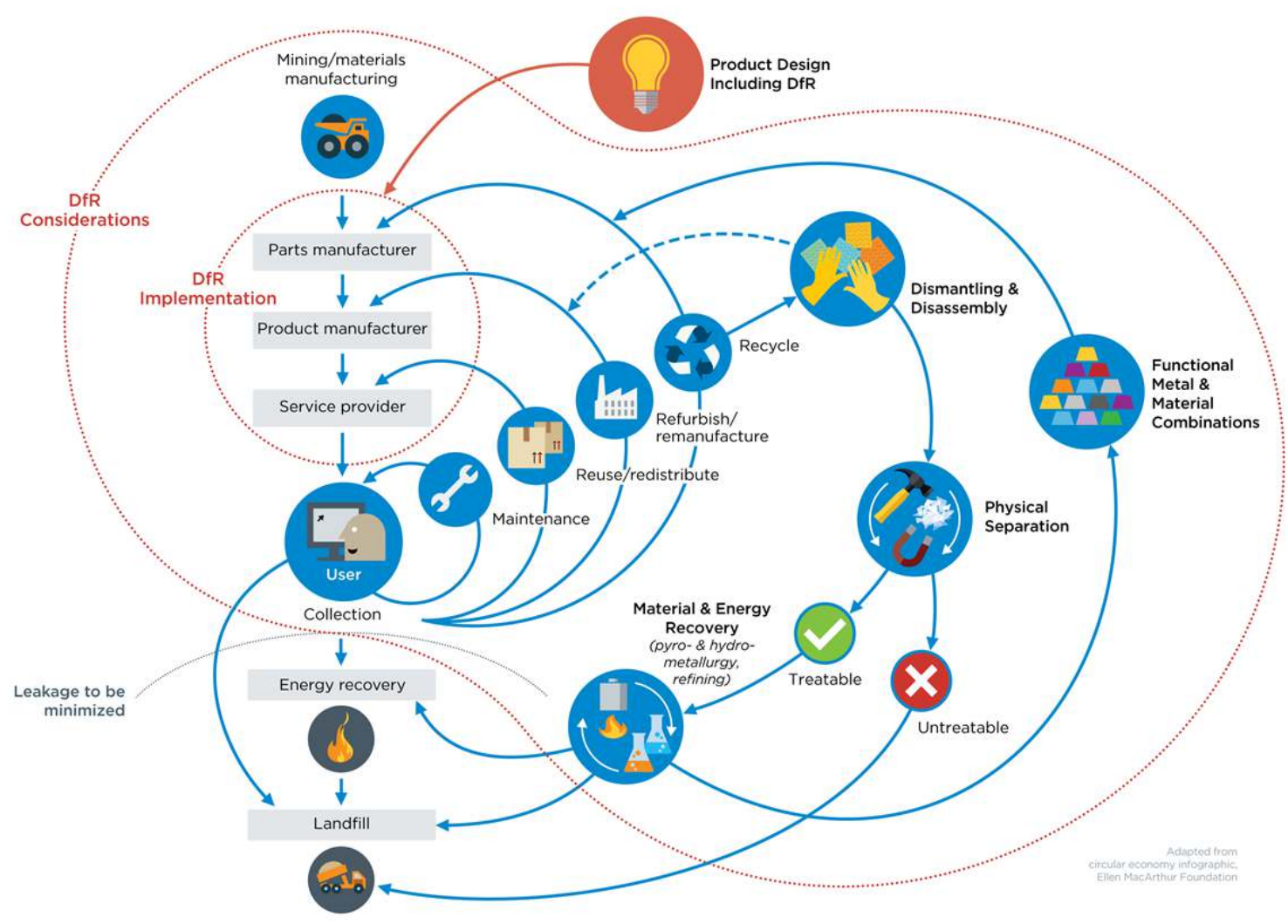

Figure 2. The role of DfR within a circular system. The large red-dotted boundary encompasses various activities which should be considered in DfR, whereas the small red-dotted circle encompasses stakeholders that directly implement DfR; service providers are included because their feedback can inform product manufacturers on DfR. The dashed blue line denotes direct reuse of intact recovered components. (Adapted from [20]) 


\section{General Guidelines}

1. Product requirements such as functionality, longevity, durability, reliability, and cost are critical; DfR should support or enhance these aspects but may result in tradeoffs between recyclability and product performance and cost.

2. Material choice and the ability to liberate separate materials are critical to DfR outcomes.

3. Recycling outcomes can be enhanced by minimizing hazardous materials in products, or by recovering these materials completely via DfR.

4. Minimizing and managing hard-to-recycle materials can improve overall recycling yield.

5. Minimizing non-reversible adhesives or similar bonds, especially over whole surfaces and for dissimilar materials, can facilitate disassembly and material liberation.

6. Design for disassembly (DfD) can improve recyclability.

7. Estimating recyclability improvements and economic and environmental impacts due to DfR is important for continuous improvement, identification, and weighing of trade-offs and communicating value.

8. Using labels to identify recyclable and non-recyclable materials helps recyclers classify feedstocks; labelling standardization is important for uptake and utilization.

9. Designing products to use recycled materials promotes circular manufacturing.

\section{c-Si PV Guidelines}

1. Durable identification of module construction and composition could enable safer and more efficient recycling processes.

2. Backsheet composition has particularly important implications for recyclability.

3. Metal choices can have significant impacts on recycling processes and costs.

4. Minimizing encapsulant use or using reversible encapsulants can facilitate disassembly of PV modules.

5. Decreasing the number and complexity of module materials presents trade-offs related to recyclability and economics.

6. Using different sealants in the aluminium frame could enable module separation without component damage. 


\section{GENERAL DFR GUIDELINES}

Based on our literature review and consultation with experts, we identify nine general DfR guidelines described below. Because DfR is product and situation specific, these guidelines must be adapted to particular cases as necessary. For example, DfR may need to consider the recycling capabilities of regions in which a product is likely to reach EOL [10]. Specific technical considerations are also important, such as whether the product will require only mechanical separation or whether it will require thermal or chemical processing. Guidelines specific to PV modules are provided in Section 3.

1. Product requirements such as functionality, longevity, reliability, and cost are critical; DfR should support or enhance these aspects but may result in trade-offs between recyclability and product performance and cost.

DfR products must be accepted in the market for the recycling benefits to be achieved, and that requires that the function, reliability, and cost be acceptable to the consumers. In some cases, improving a product's recyclability may also improve its performance and/or cost, and these win-win solutions should be sought; however, in some case these different objectives could conflict. If a high degree of recyclability impairs a product's commercial viability, designing for less recyclability may be necessary [5]. Conversely, if a product is subject to recycling targets (e.g., due to government policies), lower performance or higher cost may be trade-offs for greater recyclability.

\section{Material choice and the ability to liberate separate materials are critical to DfR outcomes.}

DfR outcome metrics like material recovery rate and purity of recovered materials depend on the choice and distribution of materials within the product as well as use of adhesives (see Guideline 6) [5, 8, 9]. For materials to enter secondary material markets, they must meet purity specifications, where sometimes specific materials mixed together make them incompatible for certain markets. If incompatible materials are used in different components or parts of a product, but are not adhered together, they can sometimes be adequately separated to not result in commingling of the recycling output streams. An example is when the incompatible materials are isolated in easily separable components. However, even if incompatible materials are in the same component, materials could potentially be separated in a recycling process. For example, shredding might be able to liberate and separate copper $(\mathrm{Cu})$ and iron sufficiently from a product to provide an acceptably clean stream of recycled iron to a steel mill that is not contaminated with $\mathrm{Cu}[8]$.

3. Recycling outcomes can be enhanced by minimizing hazardous materials in products or recovering these materials completely via DfR.

Hazardous materials should be avoided when possible (e.g., when not contrary to Guideline 1) so as not to risk classifying the product as a hazardous waste at EOL, to reduce the cost of EOL recycling (in handling and treating hazardous materials/waste), and to reduce environmental impacts of the product. When it is infeasible to avoid using hazardous materials in a product, DfR that enables full and separately controlled recovery of these materials can avoid contamination of recycling outputs and having the outputs characterized as hazardous waste. For example, recycling rates for lead-acid car batteries exceed $90 \%$. By recovering most of the lead $(\mathrm{Pb})$ and using the recycled $\mathrm{Pb}$ in new battery applications, this hazardous material is kept out of the landfill and avoids contaminating other waste streams [21]. Similarly, cadmium telluride (CdTe) PV modules are subject to a specialized process that recovers $\mathrm{Cd}$ and Te, therefore avoiding Cd release to the environment or human exposure [22, 23]. 


\section{Minimizing and managing hard-to-recycle materials can improve overall recycling yield.}

Hard-to-recycle materials vary by recycling situation and may include materials degraded by recycling or those not recyclable more than a few times, such as treated wood [5, 6] [J. Bilbao, personal communication]. When such materials must be used, DfR that makes them easy to isolate early in the recycling process can facilitate recycling of the product's other materials.

5. Minimizing non-reversible adhesives or similar bonds, especially over whole surfaces and for dissimilar materials, can facilitate disassembly and material liberation.

Non-reversible adhesives or similar difficult-to-break bonds may impede product disassembly and material liberation [5]. This is especially true when two dissimilar and incompatible materials are bonded together; however, in some cases, such bonds can facilitate recycling, such as when strategically placed welds (non-reversible) provide a better path of preferential breakage and liberation during shredding, compared with using bolts (reversible).

\section{Design for disassembly (DfD) can improve recyclability.}

DfD promotes modular product construction, which can facilitate separation and then recycling of individual component groups at EOL (as well as repair of components individually, as opposed to needing to disassemble a whole device to repair the faulty component). In addition, product disassembly trials by manufacturers can reveal implications of various aspects of the product's design with regard to DfR such as choice and location of fasteners and joining methods [10, 24], and these insights can then be applied in designing a recycling process. Design for remanufacturing exhibits similar synergies with $\operatorname{DfR}[5,6]$.

7. Estimating recyclability improvements and economic and environmental impacts due to DfR is important for continuous improvement, identification, and weighing of trade-offs and communicating value.

In recent years, methods designed to quantitatively [8, 9, 10, 24] or qualitatively [5] analyse product recyclability have emerged. These methods, which vary in complexity and ease of use, are most useful when validated with experimental observations, and yet can themselves be improved. DfR can be beneficial even if product designers can only assess its impacts at a more informal level $[5,8,9,10,24]$. Benefits from analysing effects of recycling include the ability to learn and continuously improve, to identify any trade-offs (drawbacks), and then weigh their effect for future redesign, as well as to be able to communicate the value of DfR to internal and external stakeholders.

8. Using labels to identify recyclable and non-recyclable materials helps recyclers classify feedstocks; labelling standardization is important for uptake and utilization.

Product labelling options include stickers with identifying information, symbols, embossed or engraved information, bar codes, radio-frequency identification (RFID), blockchain (e.g., [25]), material passports (e.g., [26, 27]), or other methods. The label composition, placement, and application method can have positive or negative recycling implications, but the label's information is most important $[5,8,9]$. Clear labels help recyclers classify feedstocks and thus facilitate their entire recycling operations [3,21]. Standardization is key to efficiency of use, degree and ease of uptake, and broad utilization. Confidential or proprietary information can be maintained in some systems, with potential trade-offs in ease and speed of identification by multiple parties. Labels providing additional information beyond just material composition can also be helpful (i.e., appropriate handling and recommended repair, remanufacture, and recycle strategies). 
9. Designing products to use recycled materials promotes circular manufacturing.

Although using recycled materials in a product does not inherently improve that product's recyclability, doing so bolsters the circularity of the manufacturing system and encourages DfR $[3,5,6]$. In turn, increasing the prevalence of DfR may lead to higher-quality recycled feedstocks and greater utilization of these resources. 


\section{PV DFR GUIDELINES}

PV module recycling provides value from materials recovery [28] and benefits to the environment including reduced energy use and emissions associated with producing raw materials, such as producing Si for c-Si modules (which is among the highest-impact moduleproduction steps [29,30]). For example, Al for module frames has an energy demand of about $200 \mathrm{MJ} / \mathrm{kg}$ for primary production [31], whereas Al recycling requires only $8 \mathrm{MJ} / \mathrm{kg}$, and a module's Al frame is the most accessible material to recover. As another example, recycling module glass can reduce energy consumption by approximately $40 \%$ compared with energy used for primary glass production [32]. PV DfR is necessary to maximise recovery of highquality materials and minimise negative environmental impacts.

This section starts with DfR guidelines applicable to the world's dominant PV technology, c-Si PV (Section 3.1), some of which also apply to structural aspects of DfR for thin-film PV modules. Section 3.2 provides a short discussion of additional DfR considerations for thin-film PV. Section 3.3 discusses junction box recycling, and Section 3.4 addresses the issue of durability vs. recyclability.

\subsection{General and c-Si PV DfR Guidelines}

PV cells can be made of different materials, but the bulk of the market has been based on cSi technologies [33]. A c-Si cell is usually about 150-180 $\mu \mathrm{m}$ thick [33], and it is commonly composed of a Si wafer, Si nitride $\left(\mathrm{SiN}_{\mathrm{x}}\right)$ antireflection layer, $\mathrm{Ag}$ front electrode, and $\mathrm{Al}$ back electrode. Passivated emitter rear contact (PERC) cells, the current leading C-Si technology, have a slightly different configuration compared with standard Al back-surface-field (AI-BSF) cells; a dielectric passivation layer on the rear of PERC cells improves light capture and reduces electron recombination. In a module, the cells are interconnected by soldering $\mathrm{Cu}$ wires, typically using a $\mathrm{Pb}$-based soldering paste.

The basic design of c-Si modules has not changed for decades, although manufacturers have created thousands of variations. Such variability challenges the design and economics of recycling systems, and of PV DfR. Another challenge is that PV systems are expected to perform with high reliability for warrantied periods of 2-3 decades under extremes of outdoor environmental conditions. Such stringent performance requirements have incentivized a design philosophy leading to a sealed, durable, sandwich-like structure that challenges separation and liberation of constituent materials.

Based on experience from laboratory experiments through industrial-scale processes, removing the ethylene vinyl acetate (EVA) layer is one of the most challenging recycling steps [34]. The challenge to recover intact cells from a PV recycling process is to develop a gentle method, so the cells remain unbroken. Different research groups have attempted to detach the cells from the EVA encapsulant, but the results have not been completely successful with regard to cell breakage [34]. The use of $\mathrm{HNO}_{3}$ to dissolve EVA was tested, but this method takes a long time (approximately 24 hours), and the process damages cell components including the Ag and Al electrodes [35]. Other solvents were also tested to dissolve the EVA, such as organic solvents (e.g., toluene, benzene, trichloroethylene) [36]. However, these processes are also slow, taking weeks to finish the chemical reaction. Researchers used an ultrasonic bath [37] to speed up the chemical process, but cost and energy inputs were high. A different approach is the thermal decomposition of EVA [38, 39, 40, 41] in which an exothermic reaction burns the EVA. Reclaimed cells often suffer damage during the thermal and chemical processes. 
If intact cells can be recovered from PV modules, new cells could be fabricated using the recycled wafers as raw materials. A reclaimed cell must be prepared for use as a new wafer, which includes removing the $\mathrm{Ag}$ and $\mathrm{Al}$ electrodes, $\mathrm{SiN}_{\mathrm{x}}$ layer, emitter, and back-surface field. Chemicals proposed for these processes include hydrogen fluoride (HF; removes $\mathrm{SiN}_{\mathrm{x}}$ and $\mathrm{Al}$ ), $\mathrm{HNO}_{3}$ (reacts with $\mathrm{Ag}$ ), $\mathrm{HF}$ and $\mathrm{HNO}_{3}$ (for $\mathrm{Si}$ and $\mathrm{SiN}_{\mathrm{x}}$ ), and potassium hydroxide $(\mathrm{KOH}$ ) or phosphoric acid $\left(\mathrm{H}_{3} \mathrm{PO}_{4}\right)$ (removes $\mathrm{Al}$ ) [42, 43, 44, 45].

Among various existing c-Si PV module recycling concepts $[46,28,47,48,49,50,51,52,53$, $54]$, [55, 56, 57, 16, 58, 59], three have achieved pilot scale or larger: hot-knife (thermal) glass separation process offered by NPC $[48,49,60]$, a mechanical-only process run by Veolia [50, $51,52,53]$, and a mechanical-chemical process designed in the Full Recovery End of Life Photovoltaic (FRELP) research project $[46,54,55]$, which span the entire scope of potential cSi PV recycling considerations and impacts (Table 2). Collectively, these include varying combinations of mechanical, thermal, and hydrometallurgical unit operations. All options, except the Veolia process, subject virtually the entire module's polymer content to some form of thermal treatment.

\section{Table 2. Descriptions of Three Existing c-Si PV Recycling Processes}

\begin{tabular}{|c|c|c|c|}
\hline Process & Separation type & Resulting products & Status \\
\hline $\begin{array}{l}\text { Hot- } \\
\text { knife } \\
{[48,49,} \\
60]\end{array}$ & $\begin{array}{l}\text { Mechanical + thermal } \\
\text { (Cu smelter) }\end{array}$ & $\begin{array}{l}\text { Aluminium (Al) frame, glass pane or } \\
\text { cullet (to market) backsheet + cell + } \\
\text { ethylene-vinyl acetate (EVA) sandwich } \\
\text { (sold to } \mathrm{Cu} \text { smelter) } \\
\mathrm{Cu} \text {, silver }(\mathrm{Ag}) \text {, and potentially } \mathrm{Pb} / \text { tin } \\
\text { (Sn) (post smelting) }\end{array}$ & $\begin{array}{l}\text { Pilot scale, } \\
\text { Japan }\end{array}$ \\
\hline $\begin{array}{l}\text { Veolia } \\
{[50,51} \\
52,53]\end{array}$ & Mechanical only & $\begin{array}{l}\text { Al frame, junction box, external cables, } \\
\text { two grades of glass cullet products, two } \\
\text { particle sizes of a mixed plastic product, } \\
\text { two grades/particle sizes of Si product, } \\
\text { and a Cu-bearing metals fraction }\end{array}$ & $\begin{array}{l}\text { Commercial } \\
\text { scale, } \\
\text { France }\end{array}$ \\
\hline $\begin{array}{l}\text { FRELP } \\
{[46,54,} \\
55]\end{array}$ & $\begin{array}{l}\text { Mechanical, thermal, } \\
\text { hydrometallurgical }\end{array}$ & $\begin{array}{l}\text { Al frame, glass cullet, } \mathrm{Ag}, \mathrm{Cu} \text {, } \\
\text { metallurgical-grade } \mathrm{Si}\end{array}$ & $\begin{array}{l}\text { Pilot scale, } \\
\text { Italy }\end{array}$ \\
\hline
\end{tabular}

Based on our review of recycling processes, we identified the following DfR guidelines to be applicable across c-Si technologies. In addition, DfR for PV modules must consider current market (price, performance) and safety certification expectations as the starting point for any proposed changes.

1. Durable identification of module construction and composition could enable safer and more efficient recycling processes.

Identification of module composition and construction may permit higher tolerance for variable module designs that are otherwise suboptimal from a recycling perspective, because the recycling process can be designed to accommodate known variability. Known composition could also facilitate batch processing of categorized groups, enable isolation of problematic or incompatible chemical compositions, and avoid contamination of recycling products. Because modules may outlive their manufacturers, it would be helpful for labelling to be durable (on the 
scale of decades) and for any linked databases of construction or composition to remain accessible after a manufacturer goes out of business. Steps in this direction are being taken. Although currently limited, a new voluntary sustainability certification standard, NSF-457, includes provisions for identifying PV module compounds [59]. Emerging regulations in France surrounding minimization of PV's carbon dioxide footprint will require manufacturers to identify module composition details [61, 62].

\section{Backsheet composition has particularly important implications for recyclability.}

Backsheet design has module cost and performance implications, as well as impacts on recyclability [55]. Tedlar, made of the fluoropolymer polyvinylfluoride (PVF), is commonly used for the backsheet layer in c-Si modules. However, such backsheets containing fluorinated polymers produce hazardous fluorine $(F)$-bearing gases under thermal processing and thus increase thermal recycling costs or restrict treatment options. For example, the use of pyrolysis is challenged because the pyrolysis oil becomes contaminated with $F[55,63,64,65,66,67]$. If thermal processing is not used, backsheet composition has less effect on recyclability.

Environmental studies conclude that fluoropolymer use in PV modules must be avoided, and other polyethylene terephthalate (PET)-based or biobased materials should be used as replacements. In addition, the materials used in all PV layers must be labelled to inform users and EOL managers about health and environmental risks and appropriate EOL treatments [68].

Some segments of the PV industry have reduced module $\mathrm{F}$ content to reduce production costs (Figure 3) [69]. Recently, recyclability has become a driver of F-free backsheet manufacturing [67], particularly for higher-end modules. Transparent backsheets exist in both fluorinated [70] and F-free $[71,72]$ varieties.

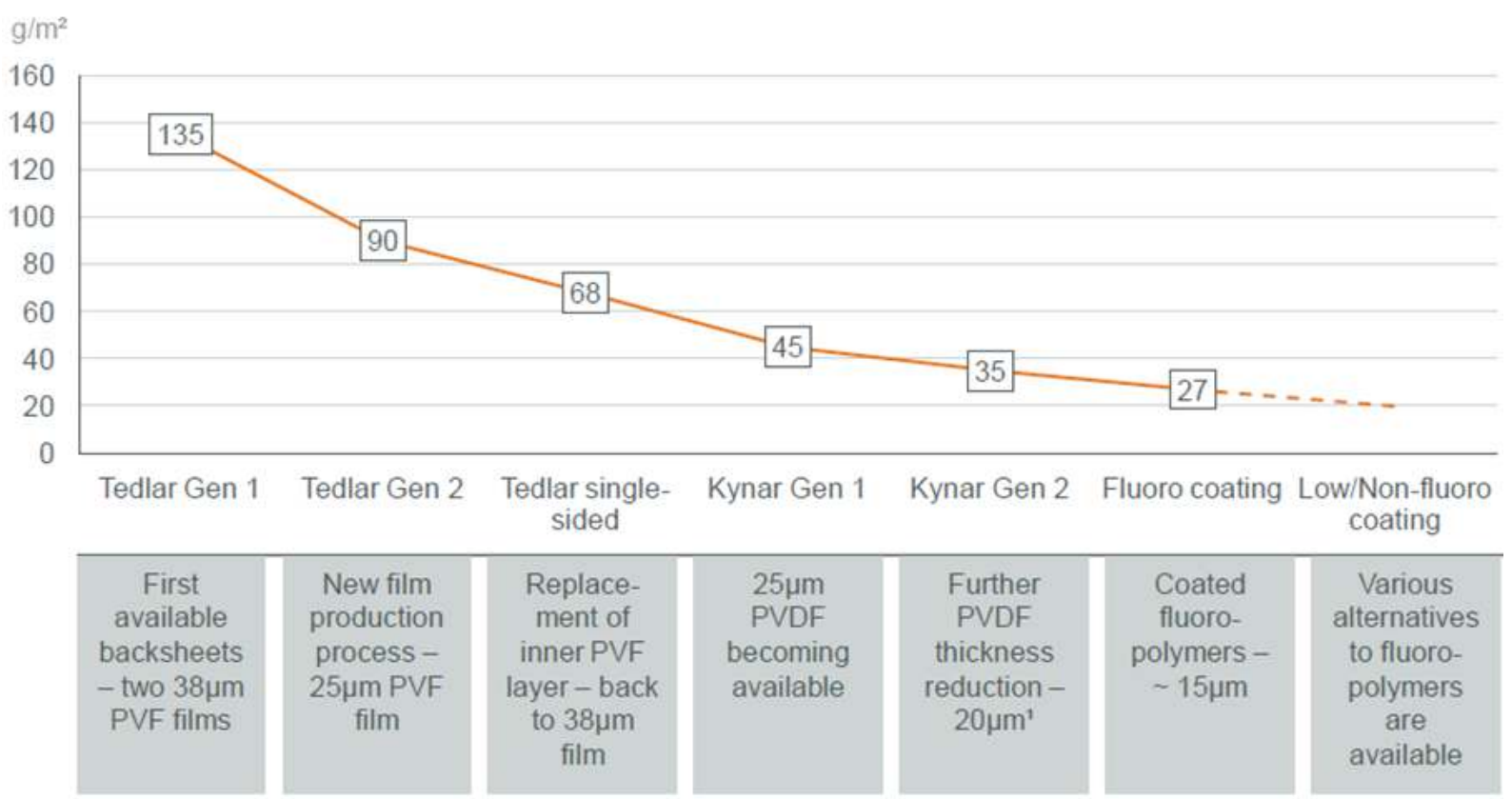

Figure 3. Historic progression (x-axis) of incremental technology improvements reducing F-content $\left(\mathrm{y}\right.$-axis, $\mathrm{g} / \mathrm{m}^{2}$ ) for modules (DSM 2018, attributed to a 2013 study by Apricum) [69] 
If fluoropolymers must be used in backsheets for a particular module design, lower $\mathrm{F}$ content is preferable for three reasons. First, air emissions from thermal processing can be controlled at lower cost owing to lower use of reagent to neutralize F. Second, the off-gases will be less corrosive. Finally, there will be a lower penalty to the price received if sending any recovered materials contaminated with $\mathrm{F}$ to $\mathrm{Cu}$ smelters.

The cost implications of recycling fluorinated backsheets have been debated. Some stakeholders say the incremental cost impact is limited, particularly where regionally available thermal treatment infrastructure is already equipped for fluoropolymers; however, the incremental cost could reach 1 U.S. dollar (USD) per module when a primary Cu smelter treats an F-bearing backsheet [73], which could be roughly equivalent to the recovered $\mathrm{Cu}$ value per module [59], thus reducing the economic feasibility of recycling. When a module's polymer content represents a potentially saleable recycling output (as with the Veolia process), backsheet content considerations depend on the local or regional recycled plastics market [50].

Future recycling processes may be able to remove fluoropolymers from backsheets mechanically $[49,74,75]$. In such a process, designs that minimize fluoropolymer coatings on the inner layers of the module would likely be easier to treat. If a future recycling option has the capability to remove and isolate a thin $(\sim 50 \mu \mathrm{m})$ layer from the exterior of a backsheet (of fluoropolymer and/or non-fluorinated base layer materials), this could improve the tolerance of recycling systems to the use of exterior fluoropolymer layers in future module designs [76]. Section 4 contains descriptions of research and development aimed at mitigating recyclability problems due to fluorinated backsheets. A trend in PV module design today that eliminates the backsheet in favour of a second layer of glass (so-called glass/glass or double-glass modules) would likely bypass the $\mathrm{F}$ issue.

Beyond F content, other backsheet attributes can affect module recyclability. For example, polymers containing nitrogen can result in nitrogen oxides during thermal treatment. Nanotitanium dioxide $\left(\mathrm{TiO}_{2}\right)$ pigment may become subject to additional regulatory hurdles, particularly in thermal treatment applications [76]. The recycling implications when using carbon black pigments or conductive backsheets are unclear [77].

\section{Metal choices can have significant impacts on recycling processes and costs.}

Substitution of $\mathrm{Ag}$ metallization with $\mathrm{Cu} / \mathrm{nickel}(\mathrm{Ni})$ presents recycling trade-offs, which depend in part on the recycling process used. Ag, one of the largest sources of module recycling revenues, is also one of the most resource-constrained PV feedstocks. Reducing Ag use in modules may be necessary to sustain rapid global PV growth [78, 79, 80, 81, 82]. Partial substitution with $\mathrm{Cu} / \mathrm{Ni}$ is less favourable than total substitution in recycling processes that use leaching, such as FRELP, owing to the additional complexity of handling both $\mathrm{Ag}$ and $\mathrm{Ni}$ in the leach solution. The presence of $\mathrm{Ag}$ makes the mixture unsuitable to alternative and lessexpensive leaching chemistries [83]. Costs for recycling processes without leaching, such as the hot-knife/Cu smelter process, likely would be less affected by partial or total substitution of $\mathrm{Ag}$ with $\mathrm{Cu} / \mathrm{Ni}$. In some cases, $\mathrm{Ni}$ can be recovered when present in a $\mathrm{Cu}$ smelter feed, and penalties likely would not be incurred if Ni concentrations are below $1 \%$ mass in the dry smelter feed [84].

Various candidates could replace $\mathrm{Pb}$ in module solder alloys, with a range of impacts on recyclability. $\mathrm{Cu}$ or $\mathrm{Ag}$ could increase recycling revenues, although using $\mathrm{Ag}$ may strain feedstock availability and increase cost. $\mathrm{Sn}$ is effectively interchangeable with $\mathrm{Pb}$ in terms of recycling impacts; $\mathrm{Sn}$ is scarcer and more expensive than $\mathrm{Pb}$, but it is more abundant and cheaper than $\mathrm{Ag}$. Bismuth $(\mathrm{Bi})$ presents the most recycling problems among $\mathrm{Pb}$-replacement 
candidates. Bi can result in higher penalties when selling $\mathrm{Cu}$-bearing recycling outputs to a $\mathrm{Cu}$ smelter, reaching 3-10 USD per tonne of smelter feed per $0.1 \%$ of excess Bi for a typical feed consisting of $22 \%-30 \% \mathrm{Cu}$ [84]. In contrast, $\mathrm{Sn}$ and $\mathrm{Pb}$ are tolerated at much higher concentrations $(3 \%-5 \% \mathrm{~Pb}+\mathrm{Sn}+$ Zinc) and incur lower penalties (1 USD per tonne per $1 \%$ mass) [84]. Bi interferes with downstream electro-refining of smelter Cu outputs, increasing complexity and cost [84]. Failure to remove $\mathrm{Bi}$ results in lower electro-refining efficiencies, higher energy intensity for PV recycling, and potential contamination of the Cu cathode; the mechanical properties of $\mathrm{Cu}$ products suffer with even $0.2 \%$ mass $\mathrm{Bi}$ contamination [85]. $\mathrm{Cu}$ refiners rely on a sulfuric acid process, but the same issues may manifest in more sophisticated PV recycling flowsheets, such as FRELP's nitric acid-based process, and could require further recycling stages. In addition, not all Bi-isolation methods yield saleable Bi outputs, so circularity of $\mathrm{Bi}$ is not assured. $\mathrm{Pb}$ and $\mathrm{Sn}$ interfere much less with such circuits and can be readily managed in FRELP's nitric acid-based process [46]. Should Bi be required in C-Si PV applications [86], some portion of the recycling impacts could eventually become more tolerable [87]. See Section 4 for additional discussion of this issue.

\section{Minimizing encapsulant use or using reversible encapsulants can facilitate disassembly of PV modules.}

Encapsulant removal poses a challenge to many PV recycling processes. The FRELP and hotknife processes use high temperatures to volatilize the encapsulant from the cells [46, 48, 54, 55]. The Veolia process separates materials encapsulated together through a complex mechanical process. This process may have more tolerance for existing encapsulants but would likely perform better without them owing to reduced cross-contamination of recycling products, improved liberation, and more homogenous plastic outputs [50, 51, 52, 53]. Several options exist for modifying PV encapsulants to facilitate recycling.

Use encapsulant with release layers-EVA is the most common PV encapsulant owing to its unique durability and transparency. However, the difficulty of separating EVA from other module components-such as cells, glass, and backsheets-hinders PV recycling. One proposed solution is adding a "release layer" as in the double encapsulation module (DEM), which aims to simplify the recovery of PV cells without changing the manufacturing process significantly (Figure 4) [88]. In addition to the typical module layers-such as glass, encapsulant (normally EVA), c-Si cell, encapsulant again, and backsheet-the DEM design inserts two non-adhesive films (release layers) between the EVA layers and the cells. These non-adhesive films are a little larger than the cells, which provides a cutting margin. When the modules achieve EOL and go to the recycling plant, the backsheet side can be cut out with a knife, and then the c-Si cells can be recovered easily. The DEM offers a good cell recovery rate and damp heat reliability [88].

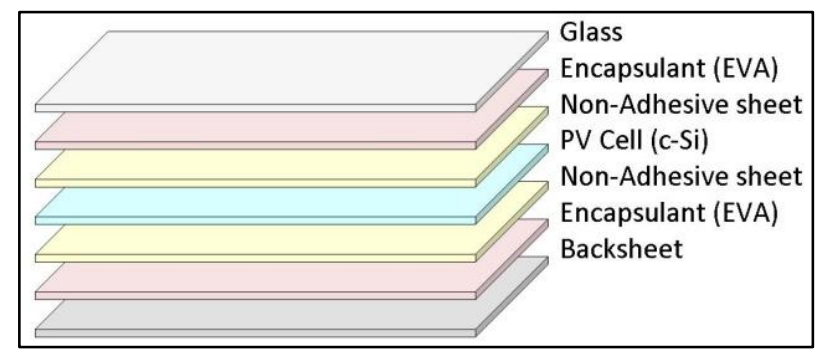

Figure 4. Proposed structure of the DEM single-cell module design [88] 
A novel double encapsulation module with an optical coupler (DEMOC) was proposed by researchers from EPFL and IMT. Adding an optical coupler enables the reuse of c-Si cells while minimising the performance loss compared with standard PV encapsulation (Figure 5). The DEMOC design has a recycling efficiency of over $97 \%$ [56]. The optical coupler material is selected based on optical transparency, refractive index matching, and heat/optical stability, and it must be compatible with the encapsulation process. In [56], a commercial grade of twocomponent liquid silicone was selected. Although the DEMOC design offers better optical performance compared to the DEM approach thanks to its optical coupler, it has higher optical losses compared to standard module designs (about $1.5 \%$ absolute reduction in $\mathrm{I}_{\mathrm{sc}}$ ).

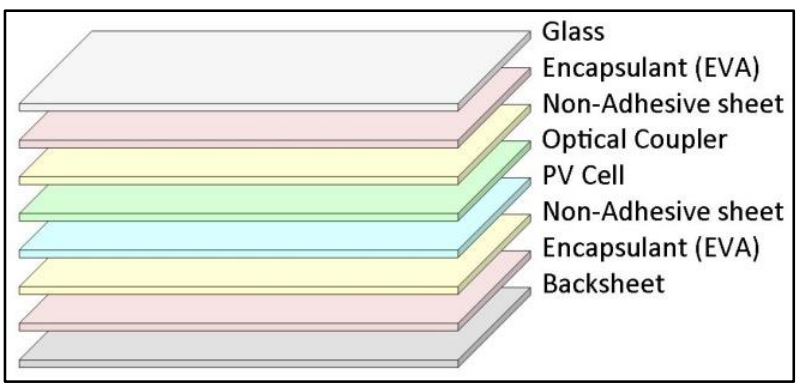

Figure 5. Proposed structure of the DEMOC single-cell module design [56]

Use no encapsulant-Producing modules without any encapsulant material is another alternative to EVA. ApollonSolar developed the NICE technology to overcome limitations of the EVA encapsulation process and reduce module production costs [89]. The NICE technology uses a polyisobutylene (PIB) material (used and validated in the insulating glass industry) [89], which has sealing properties that guarantee very high and long-term air/humidity tightness as well as the mechanical contact between module components. The NICE configuration enables simplified, manual module disassembly and recovery of components as intact parts, which increases value for recycling and reuse (Figure 6) [90,58]. However, module efficiency declines because of the air gap and electrical connections held together by internal module vacuum pressure; changes in temperature and altitude would change the electrical efficiency [91, 92, 93, 94, 90].

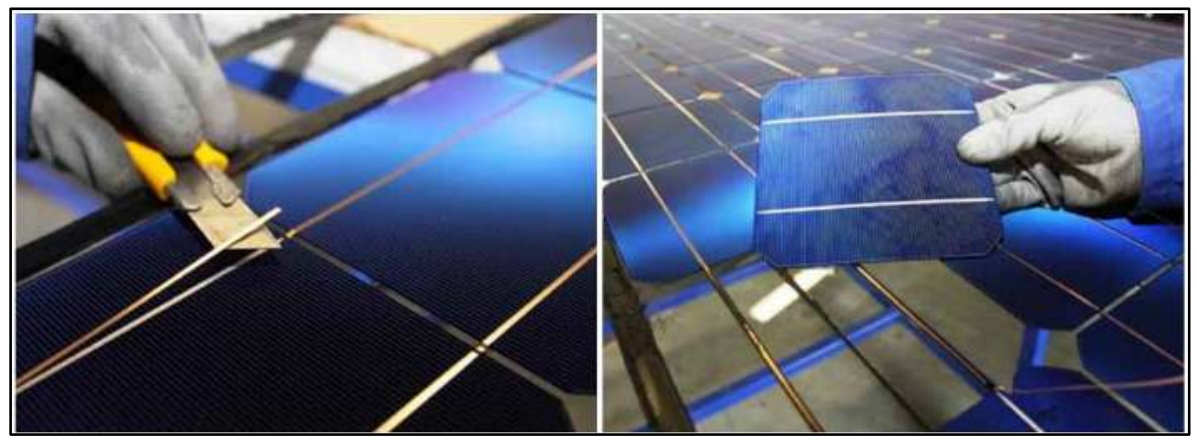

Figure 6. Manual NICE-module disassembly at ApollonSolar (from [58])

TPedge is another encapsulant-free module design. It uses adhesive pins, which cover only $0.02 \%$ of the cell surface, and soldered electrical connections that require no specific underpressure but might exhibit some sensitivity to temperature or altitude. Both NICE and TPedge eliminate encapsulant from the face of the cells with the help of edge-sealing methods like 
silicone. Still, some glue-like material is required on portions of the front glass and rear materials. Although recyclability has not been specifically demonstrated on a TPedge module, the design indicates it could be more successful than most typical modules [95, 96, 97].

Use different encapsulant materials-An alternative approach to the EVA-recycling challenge is to replace EVA with durable encapsulant materials that are not harmful when vaporised or that melt at low temperatures without degrading the substrate or absorber materials, and that are easier to disassemble and separate [98].

Thermoplastics have demonstrated some positive results in terms of their role in PV module operation and recyclability. One study compared the use of EVA in PV modules with the use of a filler sheet made of thermoplastic olefin resin [99]. The results showed that the olefin layer has high transparency and low water absorption, and its moisture barrier is much better than that of the conventional EVA sheet. Recyclability tests showed that a heating process enables separation and recovery of module components when using the olefin layer instead of EVA, though the potential for polyolefin residues to remain on the glass and cells (as can be seen in Figure 7) should be investigated with regard to end market purity requirements [99].

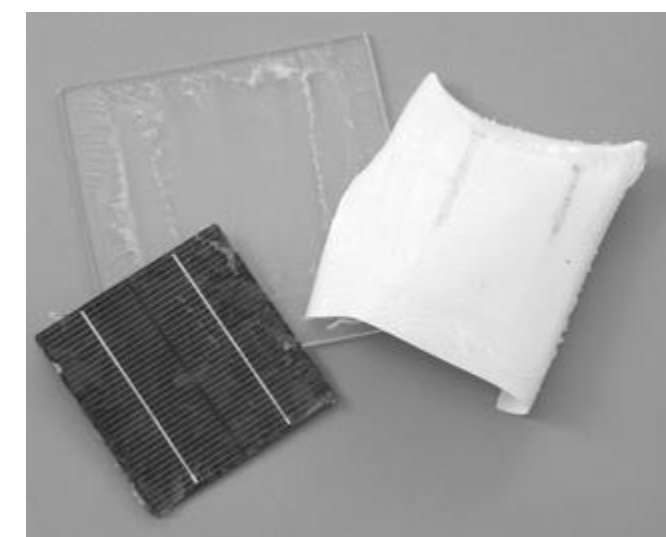

Figure 7. Cell, glass, and backsheet separated from a module constructed with an olefin layer (from [99])

Another encapsulant possibility is silicone, which is optically superior to EVA [100]. Silicone is more expensive than EVA, and the encapsulation process is more difficult [101]. However, it has shown significant advantages including increased short-circuit current density and cell efficiency under certain conditions [100,102] (although this result may not be true in dusty conditions [102]). Silicone has been found to improve average performance by $2 \% \mathrm{kWh} / \mathrm{kWp}$ depending on environmental conditions [103]. In addition, silicone-encapsulated modules increased short-circuit current density by $0.31 \%-1.45 \%$ compared with EVA-encapsulated modules owing to better ultraviolet (UV) transparency [104]. Silicone has also demonstrated recyclability benefits over EVA. Isopropanol was used to dissolve silicone-based encapsulant from c-Si modules, enabling separation of the wafer, glass, ribbon, and backsheet after two days at room temperature, and the isopropanol could be reused for a second time [57]. However, the silicone recycling results are not as promising as the results from using thermoplastics as encapsulant materials. Moreover, silicone encapsulants have been found to lose adhesive properties in extreme weathering conditions [105]. 


\section{Decreasing the number and complexity of module materials presents trade-offs related to recyclability and economics.}

Two trends in PV module designs provide examples for exploring trade-offs with regard to reducing the number and complexity of materials. PV modules are typically designed with frames, but they can be designed without frames. Choosing between a framed and frameless module design exemplifies one set of trade-offs related to recyclability and economics. Framing helps protect the module during transportation, installation, and EOL removal, eases the installation process, and provides torsional rigidity throughout the life cycle. Frameless modules are more prone to breakage, although certain transportation strategies and, for instance, reusable corner protectors can reduce breakage. On the other hand, frameless modules simplify recycling. De-framing a module adds a recycling step and increases the potential for glass and cell breakage [106]; however, the frames are relatively easy to recover, and the Al can add more than $2 \mathrm{USD} /$ module in recycling revenue [28, 59]. This makes the frame's impact on recycling economics comparable to module Ag content ( 2.70 USD/module [59]), particularly for recycling processes such as FRELP and hot-knife [46, 48, 54, 55]. As yet another trade-off, frameless modules are typically lighter (the exception being frameless glassglass modules) and more compact and can cost less to transport at EOL. If the frame is removed (whether via frameless design or frame removal at EOL), up to seven times more modules can fit in the same container [50].

Likewise, glass/backsheet versus glass/glass module designs present other trade-offs. Glass/glass designs would increase the potential glass cullet revenue per module and eliminate use of a backsheet, which is often fluorinated $[28,59]$. If the rear and front glass are of different grades and are not isolated from each other throughout the recycling process, introducing the multiple grades into outputs may degrade the glass recycling economics. Experimental recycling data are sparser for glass/glass modules than for the typical glass/backsheet varieties. Because the mechanical properties of glass differ from those of polymer backsheets, recycling processes that intentionally or coincidentally exploit such attributes could be impacted in unpredictable ways. Based on correspondence with a La Mia Energia representative (2019), the mechanical Veolia process has undergone preliminary testing with glass/glass modules, and future glass/glass recycling is possible with some retrofitting.

\section{Using different sealants in the aluminium frame could enable module separation without component damage.}

Frame removal is the first step when recycling modules that have Al frames. Most module manufacturers use high-performance silicone adhesive (e.g., DOW Corning PV-804) or double-sided adhesive tape (e.g., Duplomont) as a frame sealant. These sealant materials are difficult to remove during module disassembly, and they increase the risk of module component damage, reducing its recycling value.

O-ring and U-profile technologies are alternative, easy-to-remove edge-sealant solutions for PV modules (Figure 8). When these approaches were tested with samples relevant for foilbased back-contact PV technology, the absence of adhesion to the glass or Al frame enabled both module components to be separated easily without distortion of the Al frame or breakage of the glass sheet [106]. 


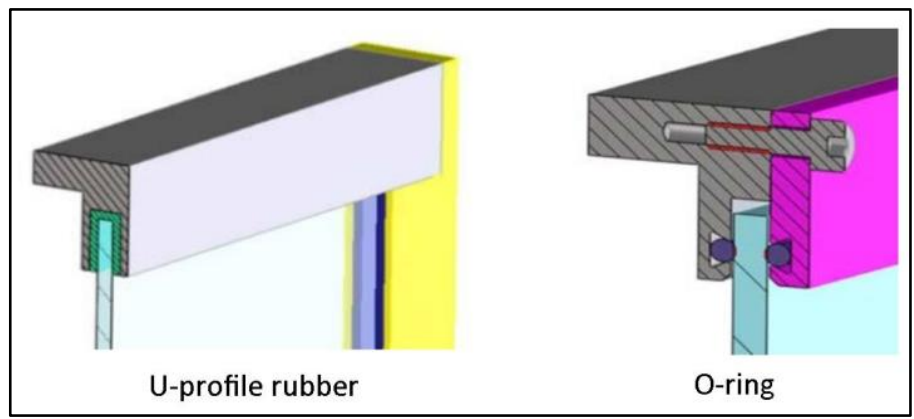

Figure 8. Schematic of sample design to test alternative edge sealants (from [106])

\subsection{Thin Film PV}

Thin-film technologies currently represent a small portion of the PV market. Although thin-film modules are technologically more varied than c-Si modules, the c-Si PV DfR guidelines pertaining to structural aspects of a module generally remain valid for a range of thin-film module chemistries. However, the metals-recovery stages of the recycling process may vary as a function of underlying module chemistry. A copper-indium-gallium-selenide (CIGS) module may require different treatment $[107,108]$ than $\mathrm{CdTe}[22,23]$ or perovskite $[109,110$, 111] modules.

Thin-film technologies such as CdTe and CIGS use materials that are environmentally sensitive and/or have limited supplies (e.g., Cd, Te and In) Because of the toxicity of cadmium and restrictions on cadmium use in products by many governments, CdTe recycling techniques have been studied intensively for many years. These modules can be recycled using a combination of mechanical and chemical treatments. Large-scale processes are still in early stages, but they are expected to improve as waste volumes increase [112].

First Solar manufactures and recycles CdTe systems [22]. Integrating these functions in the same facility and supply chain enabled the establishment of a best practice for DfR implementation: the recycling division is part of the approval chain for new module designs, ensuring recyclability is considered in developing new module designs. Additionally, raw material values are higher for $\mathrm{CdTe}$ than for $\mathrm{c}-\mathrm{Si}$, yet handling of $\mathrm{Cd}$ must be carefully controlled to ensure no environmental release.

First Solar's CdTe recycling process starts by shredding the modules via hammer mill, after which the semiconductor films are removed in a slow-leaching drum. The remaining glass is exposed to a mixture of sulphuric acid and hydrogen peroxide. Next, the glass is separated from the EVA via a vibrating screen, and sodium hydroxide is used to precipitate the metal compounds. This process recovers $90 \%$ of the glass for use in new products and $95 \%$ of the semiconductor materials for use in new modules [113].

Laboratory-scale recycling of several CIGS and perovskite module designs has been demonstrated [107, 108, 109, 110, 111]. Although perovskites are an emerging area of research, circularity appears possible, despite concerns about Pb content [109, 110].

Table 3 summarizes thin-film recycling processes. 
Table 3. Thin-Film Module Recycling Processes (from [47])

\begin{tabular}{|c|c|c|c|c|}
\hline Process & Advantages & Disadvantages & Status & Ref. \\
\hline $\begin{array}{c}\text { Organic } \\
\text { solvent } \\
\text { dissolution }\end{array}$ & $\begin{array}{l}\checkmark \text { Easy access to encapsulant } \\
\checkmark \text { Less cell damage } \\
\checkmark \text { Recovery of glass }\end{array}$ & $\begin{array}{l}\checkmark \text { Time for delamination depends } \\
\text { on area } \\
\checkmark \text { Harmful emissions and wastes }\end{array}$ & Research & [36] \\
\hline $\begin{array}{l}\text { Irradiation by } \\
\text { laser }\end{array}$ & $\checkmark$ Easy access to encapsulant & $\begin{array}{l}\checkmark \text { Slow process } \\
\checkmark \text { Very expensive equipment }\end{array}$ & Research & [114] \\
\hline $\begin{array}{l}\text { Hotwire } \\
\text { cutting }\end{array}$ & $\begin{array}{l}\checkmark \text { Low cell damage } \\
\checkmark \text { Recovery of glass }\end{array}$ & $\begin{array}{l}\checkmark \text { Other separation processes } \\
\text { required for encapsulant }\end{array}$ & Research & [115] \\
\hline $\begin{array}{l}\text { Vacuum } \\
\text { blasting }\end{array}$ & $\begin{array}{l}\checkmark \text { Removal of semiconductor } \\
\text { layers without chemicals } \\
\checkmark \text { Recovery of clean glass }\end{array}$ & $\begin{array}{l}\checkmark \text { Relatively slow process } \\
\checkmark \text { Emission of metals } \\
\checkmark \text { Further treatments needed }\end{array}$ & $\begin{array}{l}\text { Research } \\
\text { (pilot) }\end{array}$ & [116] \\
\hline Attrition & $\begin{array}{l}\checkmark \text { No use of chemicals } \\
\checkmark \text { Recovery of clean glass }\end{array}$ & $\begin{array}{l}\checkmark \text { Further chemical or mechanical } \\
\text { treatments needed }\end{array}$ & $\begin{array}{l}\text { Research } \\
\text { (pilot) }\end{array}$ & [116] \\
\hline Flotation & $\begin{array}{l}\checkmark \text { Relatively simple process } \\
\checkmark \text { Low use of chemicals }\end{array}$ & $\begin{array}{l}\checkmark \text { High losses of valuables } \\
\checkmark \text { Flotation process required }\end{array}$ & $\begin{array}{l}\text { Research } \\
\text { (pilot) }\end{array}$ & [116] \\
\hline $\begin{array}{c}\text { Physical } \\
\text { disintegration }\end{array}$ & $\checkmark$ Capable of treating waste & $\begin{array}{l}\checkmark \text { Other processes required } \\
\checkmark \text { Dusts containing heavy metals } \\
\checkmark \text { Breakage of PV cells } \\
\checkmark \text { Equipment corrosion }\end{array}$ & Commercial & [116] \\
\hline $\begin{array}{l}\text { Dry and wet } \\
\text { mechanical } \\
\text { process }\end{array}$ & $\begin{array}{l}\checkmark \text { No process chemicals } \\
\checkmark \text { Equipment widely available } \\
\checkmark \text { Low energy requirements }\end{array}$ & $\checkmark$ No removal of dissolved solids & Commercial & [117] \\
\hline $\begin{array}{l}\text { Chemical } \\
\text { etching }\end{array}$ & $\begin{array}{l}\checkmark \text { High-purity materials } \\
\checkmark \text { Simple and efficient process }\end{array}$ & $\checkmark$ Use of chemicals & Commercial & $\begin{array}{c}{[43,118,} \\
119]\end{array}$ \\
\hline $\begin{array}{l}\text { Thermal } \\
\text { treatment }\end{array}$ & $\begin{array}{l}\checkmark \text { Full removal of encapsulant } \\
\checkmark \text { Recovery of intact cell } \\
\checkmark \text { Simple and economical }\end{array}$ & $\begin{array}{l}\checkmark \text { Harmful emissions } \\
\checkmark \text { High energy requirements } \\
\checkmark \text { Cell defects and degradation }\end{array}$ & Commercial & [116] \\
\hline Leaching & $\checkmark$ Complete removal of metals & $\begin{array}{l}\checkmark \text { High use of chemicals } \\
\checkmark \text { Generation of acidic fumes }\end{array}$ & Commercial & {$[120]$} \\
\hline
\end{tabular}

\subsection{Junction Boxes}

A PV module junction box is a plastic compartment containing the module's electrical connections, including PV string connections and bypass diodes (Figure 9). Junction boxes are usually neglected in studies of PV recycling, because the boxes are easy to recover and the processes to recycle most of the materials are well known.

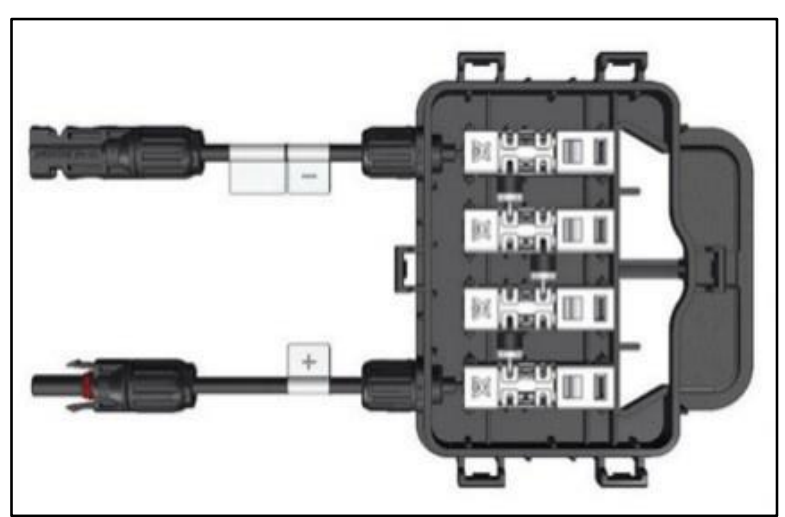

Figure 9. Example of the inside view of a PV junction box (image from [121]) 
Junction boxes are usually manually separated from PV modules, after which they can be dismantled and the materials recycled through standard electronic-waste processes. The box is made of thermoplastics filled with curing silicone (for insulation). Separating the components is possible but not always economically feasible. The most common process is to send the plastic to an incineration plant, preferably with energy recovery [122]. The cables inside the junction box contain a $\mathrm{Cu}$ conductor, which is separated from the plastics during the recycling process and recovered. Methods of recovering Cu from cables have been used in the recycling industry [123, 124, 125].

\subsection{Durability vs. Recyclability}

Recyclability refers to the ability of waste materials to be captured and separated from the waste stream for conversion into a new product or reused in the same capacity. Using recycled materials or components has potential to reduce the environmental impacts of PV production processes and EOL treatment. However, other factors also influence the environmental impact of PV.

The early 1960s mentality about product design considered durability—including longevity and repairability-but the focus changed to "short term and throw away" in the 1990s. Currently, thinking is shifting again to consider entire product life cycles from design to disposal and including function, failure, repairability, recyclability, and disposability.

One main discussion point is that durability and reliability are often inversely proportional to recyclability for PV modules. PV modules are made to withstand environmental conditions anywhere they are deployed in the world, and traditional designs "harden" the product to such an extent that they become very hard to break apart into constituent materials. In theory, a product that is durable, reliable, and recyclable would be ideal for environmentally responsible product design; in practice, these attributes define a tradeoff space [126].

Product design should consider durability because durable products can reduce the need for additional production, resulting in less EOL product volume. Recyclability should also be considered because all products reach end of life at some point, even durable ones, and it is better environmentally to recover and reuse those materials than lock them away in landfills. Combining durability with recyclability is still a challenge for PV technologies. It has been proposed that, for durable goods, policymakers can promote environmentally friendly product designs that account for both recyclability and durability [126]. In addition, the U.S. National Academies of Sciences has developed an alternatives assessment framework for use in evaluation of chemicals in products [127]. This framework could potentially be adapted to design for recycling decision-making to assist with systematic evaluation of trade-offs between durability and recyclability. 


\section{FUTURE TECHNOLOGIES}

\subsection{Pilot-Scale PV Pyrolysis Plant}

A PV recycling pilot plant in Germany is attempting to demonstrate that pyrolysis of $F$-bearing backsheets and, by extension, fluoropolymers as a whole is technically viable beyond laboratory-scale applications. This is reportedly being facilitated via the addition of an afterburner to combust the initial pyrolysis F-bearing oil product, yielding both further heat for the pyrolysis reactions as well as forcing the $F$ into conventional off-gas treatment [128]. Success of this pilot may result in fluoropolymers representing less of a penalty to recyclability than at present. Further details surrounding this pilot plant were currently unavailable.

\subsection{Selective Chiselling of PV Layers}

At least two recent studies [74, 75] and one previous pilot plant [49] include scouring or milling of the entire backsheet prior to further PV recycling, with a goal of facilitating downstream thermal treatment via upstream removal of fluoropolymers.

While technically viable, albeit challenging, full removal of the entire backsheet is likely not required to achieve the desired benefits. Outer fluoropolymer coatings on backsheets are generally $10 \%-20 \%$ of the total original backsheet thickness (less erosion during operation). One could remove $50 \mu \mathrm{m}$ of material and be assured that an outer $\mathrm{F}$ layer has been adequately removed [129]. While inapplicable for removing an inner fluoropolymer layer, it would likely

exhibit a faster throughput and less expensive wear rates in a recycling operation than total mechanical removal. Additionally, there are few recycling penalties to removing any portion of the F-free core material; thus, tight individualized depth control per module is not required beyond assuring a certain across-the-board minimum thickness is being removed.

Should this strategy prove operationally and commercially viable, this would have implications on the DfR tolerances for fluoropolymer coatings for outer layers of backsheets. It is conceivable that a unit option could be retrofitted into the early stages of all three of the PV recycling flowsheets presented in Table 2 [46, 48, 50, 51, 52, 53, 54, 55]. At the most extreme, if full backsheet removal proved viable, even inner fluoropolymer layers for the backsheets may be considered acceptable from a DfR perspective.

An additional benefit of such a process is that it potentially enables the PV recycler to realize revenue on a reclaimed mixed plastics product contingent on the regional market conditions. Given that fluoropolymers are generally denser than the F-free core materials, prospects for even further separation into multiple higher-purity polymer products from the scoured backsheet fraction are potentially also viable. This is in contrast to existing processes such as the hot-knife and FRELP processes, in which all of the backsheet material is subjected to incineration, thus eliminating any potential to realize any plastics revenue.

\subsection{Improved Bi Handling in Cu Refining}

Unrelated to shifts in the PV sector, the Cu smelting and refining industry is being forced to contend with increasing $\mathrm{Bi}$ contents in virgin $\mathrm{Cu}$ concentrates commensurate with worldwide increases in orebody complexity [87]. While several options exist for treating $\mathrm{Bi}$ in $\mathrm{Cu}$ refining, with some possessing the capacity to produce saleable Bi by-products [130], new or improved options could emerge as a matter of necessity. Coupling this with both the price and potentially 
increasing demand for $\mathrm{Bi}$, the smelting and refining industry is motivated to adopt such developments $[87,131]$. The use of $\mathrm{Bi}$ as a substitute for $\mathrm{Pb}$ solder in $\mathrm{PV}$ applications may eventually present less of a DfR challenge. Furthermore, it is possible that such techniques could transfer to recycling flowsheets, turning $\mathrm{Pb}$ waste into $\mathrm{Bi}$ revenue. 


\section{COMMERCIAL IMPLICATIONS OF DFR}

The successful application of DfR principles offers potential for environmental benefits as well as economic benefits to manufacturers and end users. With the development of regulations for electronics, such as the European Union's WEEE Directive [132], electronics manufacturers-including the PV industry-are increasingly being encouraged to invest in DfR. For example, the European project "Towards Zero Waste in Industrial Networks (Zero WIN)" [133] integrated design for recycling, repair, refurbishment, and reuse (D4R) criteria. This project focused on the development of power conditioning, lithium-ion battery systems, and industrial synergies to be demonstrated within final PV power plants. A case study was used to investigate optimal approaches to designing, manufacturing, integrating, operating, and decommissioning PV systems to create functional industrial networks during their lifetimes (in this case, 20 years) [133].

Emerging business models, such as product-as-a-service (PaaS), may enable a manufacturer to leverage recyclability as a way to reduce prices beyond what competitors can offer with comparable but less-recyclable products. While not a PV product, it is instructive to consider the business model of PaaS in another sector. Rentable vanadium (V) electrolytes for vanadium flow redox batteries (VFRBs) are one prominent clean-energy example of a PaaS business model [134]. Because the vertically integrated $\mathrm{V}$ miner/electrolyte manufacturer knows that the $\mathrm{V}$ will remain recoverable and recyclable after 10-20 years of operation, they are willing to enter into rental contracts with an end user of the battery [135]. If the $\mathrm{V}$ miner/electrolyte manufacturer rents $\mathrm{V}$ to the end user, both the battery maker and end user are decoupled from full exposure to the volatile cost of $\mathrm{V}$. This reduces the end user's upfront VFRB purchase cost (by as much as 30\% in one estimate [135]), making it competitive with lithium-ion batteries [135]. The result is a more circular economy with regard to material flow and a business model in which a finite mineral reserve translates into recurring annual payments for the $\mathrm{V}$ miner long after digging has ceased. Such alternative business models, which might become applicable to PV in the future, inherently rely on assurance that EOL collection and recycling is possible.

To maintain a high degree of recyclability, it is critical for product developers to maintain a working awareness of potentially applicable recycling processes. In this way, DfR is easier to implement in situations where the manufacturer is also a recycler of its own products, whether through PaaS models, such as the $\mathrm{V}$ rental described above, or through extended producer responsibility schemes like those for lead-acid batteries in the United States or PV in Europe's Waste Electronic and Electrical Equipment (WEEE) Directive (or, even more directly, like First Solar's takeback and recycling of its modules [136]).

Realizing a circular economy requires attention to many factors and coordination among numerous stakeholders (Figure 2). Recycling and DfR are important aspects of this effort, but they should be considered after other circular approaches, such as design for reuse, product longevity, and remanufacturing, which provide better material value retention. Economics, product performance, and environmental impacts must be considered; recycling at EOL may not always be the best solution for the existing manufacturing and recycling ecosystem. Ultimately, it is desirable to achieve system-wide goals, such as ensuring material supply, maximizing material value, or minimizing life cycle impacts.

DfR is inherently challenged by the time that elapses between manufacturing of a product and the product's EOL. A conservative approach is to design products with some assurance of recyclers' ability to handle the materials at EOL. Manufacturers can take calculated risks based 
on knowledge of potential future recycling methods, and they can mitigate risk further by becoming directly involved in planning future recycling capabilities. The market for materials will drive the success of recycling, and can help to focus DfR efforts.

Because DfR is not yet incorporated in most past and current module designs, additional research and development and optimisation of recycling processes will be essential to realising the full potential of material recovery. It is crucial to understand module materials and identify which components impede the recycling process. At the same time, the feasibility of DfR options must be considered, with regard to performance, cost, environmental impacts, and reproducibility of methods. The IEA-PVPS/IRENA "End-of-Life Management: Solar Photovoltaic Panels" report identifies the principles of PV DfR [112]. Ultimately, the success of $\mathrm{PV}$ recycling will depend on participation of the PV industry and governments. 


\section{REFERENCES}

[1] Institute of Scrap Iron and Steel, Inc., "Design for Recycling," Phoenix Quarterly, vol. 18, no. 1, pp. 8-10, 1986.

[2] E. Masanet and A. Horvath, "Assessing the Benefits of Design for Recycling for Plastics in Electronics: A Case Study of Computer Enclosures," Materials \& Design, vol. 28, pp. 1801-1811, 2007.

[3] J. Fiksel, "Design Rules and Guidelines," in Design for Environment: A Guide to Sustainable Product Development, New York, McGraw-Hill, 2009, pp. 117-162.

[4] M. C. Den Hollander, C. A. Bakker and E. J. Hultink, "Product Design in a Circular Economy: Development of a Typology of Key Concepts and Terms," Journal of Industrial Ecology, vol. 21, pp. 517-525, 2017.

[5] N. Hultgren, "Guidelines and Design Strategies for Improved Product Recyclability - How to Increase the Recyclability of Consumer Electronics and Domestic Appliances Through Product Design," Chalmers University of Technology (Thesis, https://pdfs.semanticscholar.org/ddbd/c91c3fb5fedfa094cc32bf07c2554aab81c9.pdf), Gothenburg, Sweden, 2012.

[6] T. Gaedel and B. Allenby, "Design for Recycling," in Design for Environment, Upper Saddle River, NJ, Prentice Hall, 1996, pp. 89-103.

[7] J. Tao and S. Yu, "Review on Feasible Recycling Pathways and Technologies of Solar Photovoltaic Modules," Solar Energy Materials and Solar Cells, vol. 141, pp. 108-124, 2015.

[8] M. A. Reuter and A. Van Schaik, "Product-Centric Simulation-Based Design for Recycling: Case of LED Lamp Recycling," Journal of Sustainable Metallurgy, vol. 1, pp. 4-28, 2015.

[9] A. Van Schaik and M. A. Reuter, "Material-Centric (Aluminium and Copper) and Product-Centric (Cars, WEEE, TV, Lamps, Batteries, Catalysts) Recycling and DfR Rules," in Handbook of Recycling, E. Worrel and M. A. Reuter, Eds., Amsterdam, Elsevier BV, 2014, p. 307-378.

[10] L. Dender, C. Gates, N. Jackson, G. O'Malley, T. Okrasinski, W. Rifer, M. Schaffer and K. Wolenski, "A Practical Means for Assessing Circular Economic Value of an ICT Product," in iNEMI Going Green - CARE Innovation 2018 (https://www.inemi.org/care-innovation-2018-papers?submissionGuid=732791e0-41914ce8-814f-5aee7aada2a9), Vienna, 2018.

[11] National Conference of State Legislatures, "State Renewable Portfolio Standards and Goals," 31 December 2019. [Online]. Available: https://www.ncsl.org/research/energy/renewable-portfolio-standards.aspx. [Accessed 2020].

[12] Energy Sage, "100 Percent Renewable Targets," 2 May 2019. [Online]. Available: https://news.energysage.com/states-with-100-renewable-targets/. [Accessed 2020].

[13] RE100, "Companies," [Online]. Available: http://there100.org/companies. [Accessed 2020].

[14] IRENA and IEA-PVPS, "End-of-Life Management Solar Photovoltaic Panels," International Renewable Energy Agency and International Energy Agency Photovoltaic Power Systems (https://www.irena.org/publications/2016/Jun/End-of-life-management-Solar-Photovoltaic-Panels), 2016. 
[15] VDMA, "International Technology Roadmap for Photovoltaic Results 2016," VDMA, Frankfurt, 2017.

[16] I. D'Adamo, M. Miliacca and P. Rosa, "Economic Feasibility for Recycling of Waste Crystalline Silicon Photovoltaic Modules," International Journal of Photoenergy, vol. 4184676, 2017.

[17] C. Sener and V. Fthenakis, "Energy Policy and Financing Options To Achieve Solar Energy Grid Penetration Targets: Accounting for External Costs," Renewable and Sustainable Energy Reviews, vol. 32, pp. 854-868, 2014.

[18] W.-H. Huang, W. J. Shin, L. Wang, W.-C. Sun and M. Tao, "Strategy and Technology To Recycle WaferSilicon Solar Modules," Solar Energy, vol. 144, pp. 22-31, 2017.

[19] M. L. Bustamante and G. Gaustad, "Challenges in Assessment of Clean Energy Supply-Chains Based on Byproduct Minerals: A Case Study of Tellurium Use in Thin Film Photovoltaics," Applied Energy, vol. 123 pp. 397-414, 2014.

[20] Ellen MacArthur Foundation, "From Linear to Circular: Accelerating a Proven Concept," in Towards the Circular Economy, Ellen MacArthur Foundation (https://www.ellenmacarthurfoundation.org/assets/downloads/publications/Ellen-MacArthur-FoundationTowards-the-Circular-Economy-vol.1.pdf), 2013, p. 24.

[21] L. Gaines, "The Future of Automotive Lithium-Ion Battery Recycling: Charting a Sustainable Course," Sustainable Materials and Technologies, Vols. 1-2, no. December, pp. 2-7, 2014.

[22] A. Wade, "Evolution of First Solar's Module Recycling Technology," First Solar, Tempe, AZ, 2013.

[23] P. Sinha and A. Wade, "Addressing the Hotspots in the Product Environmental Footprint of CdTe Photovoltaics," IEEE Journal of Photovoltaics, vol. 8, no. 3, pp. 793-797, 2018.

[24] P. Vanegas, J. R. Peeters, D. Cattrysse, P. Tecchio, F. Ardente, F. Mathieux, W. Dewulf and J. R. Duflou, "Ease of Disassembly of Products to Support Circular Economy Strategies," Resources, Conservation and Recycling, vol. 135, no. August, pp. 323-334, 2018.

[25] Everledger, "Ever More," [Online]. Available: https://www.everledger.io/. [Accessed 2020].

[26] EPEA, "Circularity Passports," [Online]. Available: https://www.epea.nl/circularity-passports/. [Accessed 2020].

[27] BAMB, "Materials Passports," [Online]. Available: https://www.bamb2020.eu/topics/materials-passports/. [Accessed 2020].

[28] R. Deng, N. L. Chang, Z. Ouyang and C. Mun Chong, "A Techno-economic Review of Silicon Photovoltaic Module Recycling," Renewable and Sustainable Energy Reviews, vol. 109, no. July, pp. 532-550, 2019.

[29] E. Alsema and M. de Wild-Scholten, "The Real Environmental Impacts of Crystalline Silicon PV Modules: An Analysis Based on Up-to-Date Manufacturers Data," in 20th European Photovoltaic Solar Energy Conference, 2005.

[30] R. Frischknecht, R. Itten, P. Sinha, M. de Wild-Scholten, J. Zhang, V. Fthenakis, H. C. Kim, M. Raugei and M. Stucki, "Life Cycle Inventories and Life Cycle Assessment of Photovoltaic Systems," International Energy Agency (IEA) PVPS Task 12, Paris, 2015. 
[31] E. Balomenos, D. Panias, I. Paspaliaris, B. Friedrich, B. Jaroni, A. Steinfeld, E. Guglielmini, M. Halmann, M. Epstein and I. Vishnevsky, "Carbothermic Reduction of Alumina: A Review of Developed Processes and Novel Concepts," in Proceedings of EMC, 2011.

[32] D. Strachala, J. Hylský, J. Vaněk, G. Fafilek and K. Jandová, "Methods for Recycling Photovoltaic Modules and Their Impact on Environment and Raw Material Extraction," Acta Montanistica Slovaca, vol. 22, 2017.

[33] VDMA, "International Technology Roadmap for Photovoltaic Results 2018," VDMA, Frankfurt, 2019.

[34] E. Radziemska, P. Ostrowski, A. Cienian and M. Sawczak, "Chemical, Thermal and Laser Processes in Recycling of Photovoltaic Silicon Solar Cells and Modules," Ecological Chemistry and Engineering S, vol. 17, pp. 385-391, 2010.

[35] T. Bruton, R. Scott, J. Nagle, M. Man and A. Fackeral, "Recycling of High Value, High Energy Content Components of Silicon PV-Modules," in 12th European Photovoltaics Conference, Amsterdam, 1994.

[36] T. Doi, I. Tsuda, H. Unagida, A. Murata, K. Sakuta and K. Kurokawa, "Experimental Study on PV Module Recycling with Organic Solvent Method," Solar Energy Materials and Solar Cells, vol. 67, pp. 397-403, 2001.

[37] Y. Kim and J. Lee, "Dissolution of Ethylene Vinyl Acetate in Crystalline Silicon PV Modules Using Ultrasonic Irradiation and Organic Solvent," Solar Energy Materials and Solar Cells, vol. 98, pp. 317-322, 2012.

[38] J. Bohland and I. Anisimov, "Possibility of Recycling Silicon PV Modules," in Twenty Sixth IEEE Photovoltaic Specialists Conference, 1997.

[39] M. Born and K. Wambach, "Pyrolysis of EVA and Its Application in Recycling of Photovoltaic Modules," Journal of Environmental Sciences, vol. 16, pp. 889-893, 2004.

[40] L. Frisson, K. Lieten, T. Bruton, K. Declercq, J. Szlufcik, H. De Moor, M. Goris, A. Benali and O. Aceves, "Recent Improvements in Industrial PV Module Recycling," in 16th European Photovoltaic Solar Energy Conference, 2000.

[41] P. Dias, S. Javimczik, M. Benevit, H. Veit and A. M. Bernardes, "Recycling WEEE: Extraction and Concentration of Silver from Waste Crystalline Silicon Photovoltaic Modules," Waste Management, vol. 57, pp. 220-225, 2016.

[42] I. Röver, K. Wambach, W. Weinreich, G. Roewer and K. Bohmhammel, "Process Controlling of the Etching System HF/HNO3/H2O," in 20th European Photovoltaic Solar Energy Conference, 2005.

[43] E. Klugmann-Radziemska, P. Ostrowski, K. Drabczyk, P. Panek and M. Szkodo, "Experimental Validation of Crystalline Silicon Solar Cells Recycling by Thermal and Chemical Methods," Solar Energy Materials and Solar Cells, vol. 94, pp. 2275-2282, 2010.

[44] E. Klugmann-Radziemska and P. Ostrowski, "Chemical Treatment of Crystalline Silicon Solar Cells as a Method of Recovering Pure Silicon from Photovoltaic Modules," Renewable Energy, vol. 35, pp. 1751-1759, 2010.

[45] J. Park and N. Park, "Wet Etching Processes for Recycling Crystalline Silicon Solar Cells from End-of-Life Photovoltaic Modules," RSC Advances, vol. 4, pp. 34823-34829, 2014.

[46] L. Ramon, P. Ercole, N. Favaro and others, "Full Recovery End of Life Photovoltaic," in IEA-PVPS Task 12 Open Workshop, Amsterdam, 2014. 
[47] M. M. Lunardi, J. P. Alvarez-Gaitan, J. Bilbao and R. Corkish, "A Review of Recycling Processes for Photovoltaic Modules," in Solar Panels and Photovoltaic Materials, London, IntechOpen (http://dx.doi.org/10.5772/intechopen.74390), 2018, pp. 9-27.

[48] M. Ito, "Development of Recycling Technology of Glass and Metals from Photovoltaic Panels by Separation with a Heated Cutter," NPC Incorporated (https://www.nedo.go.jp/content/100806683.pdf), Japan, 2016.

[49] K. Komoto, "Approaches to PV Waste Management in Japan," in Workshop on PV End-of-Life management: Challenges and Opportunities, EU-PVSEC (https://www.photovoltaicconference.com/images/2016/2_Programme/parallel_events/PvProductionQualitylnnovation/Keiichi_KOM OTO.pdf), Munich, 2016.

[50] La Mia Energia s.c.a.r.I., "Circular Economy, Solar Panel Recycling," in PV in the Circular Economy (PViCE) Workshop, Golden, CO, 2019.

[51] Veolia Group, "World Premiere in Recycling Photovoltaic Panels," 2018. [Online]. Available: https://www.youtube.com/watch?v=PaUISZ2bil8. [Accessed 1 July 2019].

[52] La Mia Energia s.c.a.r.I., "PV-Morede Photovoltaic Panels Mobile Recycling Device, Deliverable D 3.3, Vehicle Homologation, Agreement Number: ECO/12/333078/SI2.658616," http://www.pvmorede.it/public/D\%203.2\%20VEHICLE\%20HOMOLOGATION.PDF, Italy, 2014.

[53] La Mia Energia s.c.a.r.I., "PV-Morede Photovoltaic Panels Mobile Recycling Device, Deliverable D 4.1, Presentation Slide, Agreement Number: ECO/12/333078/SI2.658616," http://www.pvmorede.it/public/D\%204.1\%20PRESENTATION\%20SLIDE.pdf, Italy, n.d.

[54] C. Latunussa, F. Ardente, G. A. Blengini and L. Mancini, "Life Cycle Assessment of an Innovative Recycling Process for Crystalline Silicon Photovoltaic Panels," Solar Energy Materials and Solar Cells, vol. 156, no. November, pp. 101-111, 2016.

[55] F. Ardente, C. Latunussa and G. A. Blengini, "Resource Efficient Recovery of Critical and Precious Metals from Waste Silicon PV Panel Recycling," Waste Management, vol. 91, no. May, pp. 156-167, 2019.

[56] H. Y. Li, Y. Luo-Hoffman, C. Ballif and L. E. Perret-Aebi, "Re-use of c-Si Solar Cells from Failed PV Modules," in EUPVSEC (https://www.eupvsec-proceedings.com/proceedings?paper=11151), Hamburg, 2011.

[57] P. Prado, J. Tenorio and D. Espinosa, "Alternative Method for Materials Separation from Crystalline Silicon Photovoltaic Modules," Energy Technology, pp. 277-282, 2017.

[58] M. P. Bellmann, R. Roligheten, G. S. Park, J. Denafas, F. Buchholz, R. Einhaus, I. Lombardi, B. Ehlen, K. Wambach, P. Romero and A. Bollar, "Eco-Solar Factory: 40\% Plus Eco-Efficiency Gains in the Photovoltaic Value Chain with Minimised Resource and Energy Consumption by Closed Loop Systems," in 32nd European Photovoltaic Solar Energy Conference and Exhibition (https://www.eupvsecproceedings.com/proceedings?paper=38127), Munich, 2016.

[59] G. Heath, "PV Modules End of Life Management - Towards a Recycling R\&D Roadmap," in PV in the Circular Economy (PViCE) Workshop, Golden, CO, 2019.

[60] O. Tomioka, "Japanese Companies Work on Ways To Recycle a Mountain of Solar Panels," Nikkei Asian Review, 17 November 2016.

[61] E. Bellini, "The Weekend Read: Playing by the Carbon Footprint Rules," PV Magazine International, 27 April 2019 (https://www.pv-magazine.com/2019/04/27/the-weekend-read-playing-by-the-carbon-footprint-rules/). 
[62] B. Beetz, "Interview: JinkoSolar on Why It Has Chosen a Cradle to Cradle Path," PV Magazine International, 16 May 2019 (https://www.pv-magazine.com/2019/05/16/interview-jinkosolar-on-why-it-has-chosen-acradle-to-cradle-path/?fbclid=IwAR1NB66Zx-GXCUFkTTz-gFm\%E2\%80\%A6).

[63] Fraunhofer, "Final Report: End-of-Life Pathways for Photovoltaic Backsheets," Fraunhofer Institute UMSICHT

(https://www.coveme.com/files/documenti/news/fraunhofer_final_report_eol_pathways_abstract.pdf),

Sulzbach-Rosenberg, Germany, 2017.

[64] J. Stapler, W. Barnes and W. Yelland, "Thermal Degradation of Polyvinylidene Fluoride and Polvinyl Fluoride by Oven Pyrolysis, Technical Report 69-7-CM," Clothing and Organic Materials Laboratory, U.S. Army Natick Laboratories (https://apps.dtic.mil/dtic/tr/fulltext/u2/672509.pdf), Natick, MA, 1968.

[65] S. L. Madorsky, V. E. Hart, S. Straus and V. Sedlak, "Thermal Degradation of Tetrafluoroethylene and Hydrofluoroethylene Polymers in a Vacuum," Journal of Research of the National Bureau of Standards, vol. 51, no. 6, pp. 327-333, 1953 (https://nvlpubs.nist.gov/nistpubs/jres/51/jresv51n6p327_A1b.pdf).

[66] G. Lombardo, "Effects of Pyrolysis and Incineration on the Chemical Composition of Li-ion Batteries and Analysis of the By-products," Chalmers University of Technology (Thesis, https://research.chalmers.se/en/publication/508111), Gothenburg, Sweden, 2019.

[67] B. Beetz, "Interview: DSM's Circular Solar Ambitions," PV Magazine International, 17 May 2019 (https://www.pv-magazine.com/2019/05/17/interview-dsms-circular-solarambitions/?fbclid=IwAR0752MTtzI02x4_qks261mD1q6E6Cw-cUUTVYIHMG6\%E2\%80\%A6).

[68] Fraunhofer Institute for Environmental, Safety, and Energy Technology UMSICHT, "End-of-Life Pathways for $\begin{array}{llll}\text { Photovoltaic } & \text { Backsheets," } & \text { [Online]. }\end{array}$ https://www.umsicht.fraunhofer.de/en/references/photovoltaic-waste.html. [Accessed 2017].

[69] DSM, "Endurance Backsheets, an Innovative View on Backsheet Performance," [Online]. Available: https://www.dsm.com/solutions/dsm-in-solar/en_us/technologies/pv-backsheets.html. [Accessed 3 April 2018].

[70] DuPont, "DuPont Tedlar Polyvinyl Fluoride (PVF) Films: General Properties," 2014. [Online]. Available: https://www.dupont.com/products-and-services/solar-photovoltaic-materials/technical-resources/duponttedlar-polyvinyl-fluoride-pvf-films-general-properties.html. [Accessed June 2019].

[71] Coveme, "Coveme Photovoltaic Backsheet for PV Modules," 2015. [Online]. Available: https://www.coveme.com/photovoltaic/. [Accessed June 2019].

[72] DSM, "Endurance Backsheets: Get a Grip on Module Performance," [Online]. Available: https://www.dsm.com/dsm-in-solar/en_US/technologies/pv-backsheets-old.html. [Accessed 2018].

[73] BolidenMineral AB, "Socio-economic Analysis," 2013. [Online]. Available: https://echa.europa.eu , documents > afa_sd-0042-01-sea_en.pdf. [Accessed 11 April 2019].

[74] J. Duflou, J. Peeters, D. Altamirano, E. Bracquene and W. Dewulf, "Demanufacturing Photovoltaic Panels: Comparison of End-of-Life Treatment Strategies for Improved Resource Recovery," CIRP Annals, vol. 67, no. 1, pp. 29-32, 2018.

[75] V. Fiandra, L. Sannino, C. Andreozzi, F. Corcelli and G. Graditi, "Silicon Photovoltaic Modules at End-of-Life: Removal of Polymeric Layers and Separation of Materials," Waste Management, vol. 87, no. March, pp. 97107, 2019. 
[76] K. Geretschlager, G. Wallner and J. Fischer, "Structure and Basic Properties of Photovoltaic Module Backsheet Films," Solar Energy Materials and Solar Cells, vol. 144, no. January, pp. 451-456, 2016.

[77] I. Bennet, "Conductive Backsheet for Manufacture of PV Modules with Back Contact Cells," in EU Photovoltaic Solar Energy Conference (https://www.eupvsecplanner.com/presentations/c47361/development_of_conductive_backsheet_for_manufacture_of_pv_modules_with_back-contact_cells.htm), Brussels, 2018.

[78] A. Louwen, W. Van Sark, R. Schropp and A. Faaij, "A Cost Roadmap for Silicon Heterojunction Solar Cells," Solar Energy Materials and Solar Cells, vol. 147, no. April, pp. 295-314, 2016.

[79] L. Grandell and M. Hook, "Assessing Rare Metal Availability Challenges for Solar Energy Technologies," Sustainability, vol. 7, no. 9, pp. 11818-11837, 2015.

[80] X. Wang, "Cost-Effective and Reliable Copper Plated Metallisation for Silicon Solar Cells: A Development Path," University of New South Wales (Thesis, http://unsworks.unsw.edu.au/fapi/datastream/unsworks:46100/SOURCE02?view=true), Sydney, 2017.

[81] J. L. Hernandez, K. Yoshikawa, A. Feltrin, N. Menou, N. Valckx, E. Van Assche, D. Schroos, K. Vandersmissen, H. Philipsen and J. Poortmans, "High Efficiency Silver-Free Heterojunction Silicon Solar Cell," Japanese Journal of Applied Physics, vol. 51, no. October, p. 10NA04, 2012.

[82] D. Reinwarnd, D. Pysch, N. Bay, J. Burschik, H. H. Kuenlein, F. Madon, R. Einhaus, A. Brand, V. Arya, B. Smith, D. Richter and D. Kray, "All Copper NICE Modules," in 2018 IEEE 7th World Conference on Photovoltaic Energy Conversion (WCPEC) (A Joint Conference of 45th IEEE PVSC, 28th PVSEC \& 34th EU PVSEC), Waikoloa Village, HI, USA, 2018.

[83] D. Bilczuk, O. Olvera and E. Asselin, "Kinetic Study of the Dissolution of Metallic Nickel in Sulphuric Acid Solutions in the Presence of Different Oxidants," Canadian Journal of Chemical Engineering, vol. 94, no. June, pp. 1872-1879, 2016.

[84] Ecometales, "The Economic Implications of Impurities and Contaminants in Semi-finished Mining Products," 2017. [Online]. Available: http://www.ecometales.cl/index-1.htm?lang=en. [Accessed 11 April 2019].

[85] S. Steinacker and J. Antrekowitch, "The Role and Influence of Impurities on the Quality of Copper Cathodes," in MultiScience - XXXI. microCAD International Multidisciplinary Scientific Conference (http://www.unimiskolc.hu/ microcad/publikaciok/2017/b1/B1_5_Steinacker_Stephan.pdf), Miskolc, Hungary, 2017.

[86] P.-C. Hsiao, "Eutectic Sn-Bi Alloy for Interconnection of Silicon Solar Cells," University of New South Wales (Thesis, http://unsworks.unsw.edu.au/fapi/datastream/unsworks:36365/SOURCE02?view=true), Sydney, 2015.

[87] C. Risopatron, "Impurities in Copper Raw Materials and Regulatory Advances in 2018: A Global Overview," in International Seminar on Impurities in Copper Raw Materials: Regulation and Social Receptivity about Impurities in Copper Raw Materials, Tokyo, 2018.

[88] T. Doi, S. Igari and I. Tsuda, "Development of a Recyclable PV-Module-Expansion to Multi-Cells Modules," in Photovoltaic Specialists Conference, Conference Record of the Thirty-first IEEE, 2005.

[89] E. Saint-Sernin, R. Einhaus, K. Bamberg and P. Panno, "Industrialisation of Apollon Solar's NICE Module Technology," in 23rd EU PVSEC, 2008.

[90] R. Einhaus, F. Madon, J. Degoulange and others, "Recycling and Reuse Potential of NICE PV-Modules," in World Conference on Photovoltaic Energy Conversion, Waikoloa, HI, USA, 2018. 
[91] J. Dupuis, E. Saint-Sernin, O. Nichiporuk, P. Lefillastre, D. Bussery and R. Einhaus, "NICE Module Technology - from the Concept to Mass Production: A 10 Years Review," in 2012 38th IEEE Photovoltaic Specialists Conference (https://ieeexplore.ieee.org/document/6318254), Austin, TX, USA, 2012.

[92] F. Madon, H. Colin, L. Sicot, P. Lefillastre, J. Degoulange and R. Einhaus, "Results from Extended Degradation and Outdoor Tests of NICE Modules," 2015. [Online]. Available: http://citeseerx.ist.psu.edu/viewdoc/summary?doi=10.1.1.711.6142\&rank=7. [Accessed June 2019].

[93] O. Nichiporuk, J. Dupuis, E. Saint-Sernin, J. Degoulange, P. Lefillastre and R. Einhaus, "Secured-Intrinsic Under-Pressure in NICE Modules - the Oxygen Gettering Approach," 2012. [Online]. Available: http://citeseerx.ist.psu.edu/viewdoc/summary?doi=10.1.1.704.3311\&rank=1. [Accessed June 2019].

[94] R. Couderc, M. Amara, J. Degoulange, F. Madon and R. Einhaus, "Encapsulant for Glass-Glass PV Modules for Minimum Optical Losses: Gas or EVA?," Energy Procedia, vol. 124, no. September, pp. 470-477, 2017.

[95] Fraunhofer ISE, "Reliability of TPedge PV Modules Successfully Tested," Fraunhofer ISE, Freiburg, Germany, 2017 (https://www.ise.fraunhofer.de/en/press-media/press-releases/2017/reliability-of-tpedge-pvmodules-successfully-tested.html).

[96] M. Mittag, I. Haedrich, T. Neff and others, "TPedge: Qualification of a Gas-Filled Encapsulant-Free GlassGlass Photovoltaic Module," in 31st European Photovoltaic Solar Energy Conference and Exhibition, Hamburg, 2015 (https://www.researchgate.net/publication/318226202_Tpedge_qualification_of_a_gasfilled_encapsulation-free_glass-glass_photovoltaic_module).

[97] M. Mittag, U. Eitner and T. Neff, "TPedge: Progress on Cost-Efficient and Durable Edge-Sealed PV Modules," in $33 r d \quad$ EUPVSEC, Amsterdam, $2017 \quad$ (https://www.eupvsecplanner.com/presentations/c40935/tpedge_progress_on_cost-efficient_and_durable_edgesealed_pv_modules.htm).

[98] M. J. A. A. Goris, "Recycling Friendly Design, the Cu-PV Project for Sustainable Photovoltaics," in EUPVSEC (http://iea-pvps.org/fileadmin/dam/public/workshop/11_Maurice_GORIS.pdf), Amsterdam, 2014.

[99] K. Oi, K. Ohkawa, T. Miyachi and Y. Suzuura, "Development of the Olefin Based Filler Sheet Contributing to Reuse and Recycle Systems for PV Modules," in 19th European Photovoltaic Solar Energy Conference, Paris, 2004.

[100 K. McIntosh, J. Cotsell, J. Cumpston, A. Norris, N. Powell and B. Ketola, "An Optical Comparison of Silicone

] and EVA Encapsulants for Conventional Silicon PV Modules: A Ray-Tracing Study," in Photovoltaic Specialists Conference (PVSC), 2009 34th IEEE, Philadelphia, PA, USA, 2009 (https://ieeexplore.ieee.org/document/5411624).

[101 U. Blieske and G. Stollwerck, "Chapter Four - Glass and Other Encapsulation Materials," in Advances in ] Photovoltaics: Part 2, Volume 89, Cambridge, MA, Academic Press, 2013, pp. 199-258.

[102 H. M. Walwil, A. Mukhaimer, F. A. Al-Sulaiman and S. A. M. Said, "Comparative Studies of Encapsulation ] and Glass Surface Modification Impacts on PV Performance in a Desert Climate," Solar Energy, vol. 142, pp. 288-298, 2017.

[103 B. Ketola, C. Shirk, P. Griffith and G. Bunea, "Demonstration of the Benefits of Silicone Encapsulation of PV ] Modules in a Large Scale Outdoor Array," in 25th European Photovoltaic Solar Energy Conference and Exhibition, 2010. 
[104 N. E. Powell, B. K. Hwang, A. W. Norris, B. M. Ketola, G. Beaucarne and K. R. Mclntosh, "Improved Spectral

] Response of Silicone Encapsulated Photovoltaic Modules," in Photovoltaic Specialists Conference (PVSC), 2010 35th IEEE, 2010.

[105 C. Cai, D. C. Miller, I. A. Tappan and R. H. Dauskardt, "Degradation of Thermally-Cured Silicone Encapsulant ] Under Terrestrial UV," Solar Energy Materials and Solar Cells, vol. 157, pp. 346-353, 2016.

[106 M. Goris, V. Rosca, L. Geerligs and B. D. Gier, "Production of Recyclable Crystalline Si PV Modules," in EU ] Photovoltaic Solar Energy Conference, Hamburg, 2015 (https://www.eupvsecproceedings.com/proceedings?paper=33753).

[107 A. Gustafsson, "Recycling of CIGS Solar Cell Waste Materials," Chalmers University of Technology (Thesis), ] Gothenburg, Sweden, 2014.

[108 S. Amarakoon, C. Vallet, M. A. Curran, P. Haldar, D. Metacarpa, D. Fobare and J. Bell, "Life Cycle ] Assessment of Photovoltaic Manufacturing Consortium (PVMC) Copper Indium Gallium (di)Selenide (CIGS) Modules," International Journal of Life Cycle Assessment, vol. 23, no. 4, pp. 851-866, 2018.

[109 B. Andreas, M. Petrus, N. Huber, H. Bristow, Y. Hu, T. Bein and P. Docampo, "Recycling Perovskite Solar ] Cells to Avoid Lead Waste," ACS Applied Materials \& Interfaces, vol. 8, pp. 12881-12886, 2016.

[110 J. Kadro, N. Pellet, F. Giodano, A. Ulianov, O. Muntener, J. Maier, M. Gratzel and A. Hagfeldt, "Proof-of] Concept for Facile Perovskite Solar Cell Recycling," Energy \& Environmental Science, vol. 9, pp. 3172-3179, 2016.

[111 R. Cheacharoen, C. Boyd, G. Burkhard and others, "Encapsulating Perovskite Solar Cells to Withstand Damp ] Heat and Thermal Cycling," Sustainable Energy \& Fuels, vol. 11, pp. 2398-2406, 2018.

[112 S. Weckend, A. Wade and G. Heath, "End-of-Life Management: Solar Photovoltaic Panels," IEA Photovoltaic ] Power Systems Programme and International Renewable Energy Agency, Paris, 2016.

[113 First Solar, "First Solar," 2017. [Online]. Available: http://www.firstsolar.com/.

[114 J.-Y. Huot and M. Suys, "Recycling of Solar Thin Film PV Modules and Scraps, and Closed-Loop Use of ] Metals," in Innovationsforum Life-Cycle-Strategien und Recycling für Seltene Metalle mit strategischer Bedeutung [Innovation forum for life-cycle strategies and recycling of scarce metals of strategic importance], 2011.

[115 Q. Y. Yang and S. R. Yu, "Improvement on Recycling Process and Life Cycle Assessment of Photovoltaic ] Panel," in EcoDesign 2013 International Symposium, Jeju, Korea, 2013.

[116 W. Berger, F.-G. Simon, K. Weimann and E. A. Alsema, "A Novel Approach for the Recycling of Thin Film ] Photovoltaic Modules," Resources, Conservation and Recycling, vol. 54, pp. 711-718, 2010.

[117 L. Krueger, "Overview of First Solar's Module Collection and Recycling Program," in 1st International ] Conference on PV Module Recycling, 2010.

[118 S. Kang, S. Yoo, J. Lee, B. Boo and H. Ryu, "Experimental Investigations for Recycling of Silicon and Glass ] from Waste Photovoltaic Modules," Renewable Energy, vol. 47, pp. 152-159, 2012.

[119 W. Palitzsch and U. Loser, "A New and Intelligent De-Metalization Step of Broken Silicon Cells and Silicon ] Cell Production Waste in the Recycling Procedure of Crystalline Si Modules," in Photovoltaic Specialists Conference (PVSC), 37th IEEE, 2011. 
[120 M. Marwede, W. Berger, M. Schlummer, A. Mäurer and A. Reller, "Recycling Paths for Thin-Film

] Chalcogenide Photovoltaic Waste-Current Feasible Processes," Renewable Energy, vol. 55, pp. 220-229, 2013.

[121 Dricus, "PV Junction Box: Purpose and Connection," Sinovoltaics, 9 October 2011. [Online]. Available:

] https://sinovoltaics.com/learning-center/materials/pv-junction-box-purpose-and-connection/.

[122 C. Olson, B. Geerligs, M. Goris, I. Bennett and J. Clyncke, "Current and Future Priorities for Mass and

] Material in Silicon PV Module Recycling," in 28th European Photovoltaic Solar Energy Conference and Exhibition, 2013

[123 M. C. P. B. de Araújo, A. P. Chaves, D. C. R. Espinosa and J. A. S. Tenório, "Electronic Scraps-Recovering ] of Valuable Materials from Parallel Wire Cables," Waste Management, vol. 28, pp. 2177-2182, 2008.

[124 F. Lambert, S. Gaydardzhiev, G. Léonard, G. Lewis, P.-F. Bareel and D. Bastin, "Copper Leaching from ] Waste Electric Cables by Biohydrometallurgy," Minerals Engineering, vol. 76, pp. 38-46, 2015.

[125 A. Marabini, T. Meloy, P. C. Huang and V. Alesse, "Process for Separating and Recovering Lead, Rubber ] and Copper Wires from Waste Cables". Google Patents 1992.

[126 X. Huang, A. Atasu and L. B. Toktay, "Design Implications of Extended Producer Responsibility for Durable ] Products," Management Science, 2019.

[127 National Research Council, "A Framework to Guide Selection of Chemical Alternatives," The National ] Academies Press, Washington DC, 2014.

[128 M. Hutchins, "EU Funds Pilot Plant for PV Module Recycling," PV Magazine International, 23 August 2018 ] (https://www.pv-magazine.com/2018/08/23/eu-funds-pilot-plant-for-pv-module-recycling/).

[129 G. M. Wallner and J. Fischer, "Structure and Basic Properties of Photovoltaic Module Backsheet Films," Solar ] Energy Materials and Solar Cells, vol. 144, pp. 451-456, 2016.

[130 A. Artzer, M. Moats and J. Bender, "Removal of Antimony and Bismuth from Copper Electrorefining ] Electrolyte: Part I - A Review," JOM, vol. 70, pp. 2033-2040, 2018.

[131 D. Dreisinger, "The Economic Implications of Impurities and Contaminants in Semi-finished Mining Products,"

] in The First International Seminar on Mining and Impurities: Regulation Trends, Markets and Technologies, Santiago, Chile, 2017.

[132 European Parliament and of the Council of the European Union, "Directive 2012/19/EU of the European ] Parliament and of the Council of 4 July 2012 on Waste Electrical and Electronic Equipment (WEEE)," Official Journal of the European Union, vol. L 197, pp. 138-171, 2012.

[133 P. Arranz, J. Tarragó, X. Vallvé, M. Marwede, E. Den Boer, M. Rothe, F. Wüst, A. Middendorf, J.-M ] Cocciantelli and M. Lippert, "Practical Demonstrator "Design for Recycling Photovoltaic System"," in Electronics Goes Green 2012+(EGG), IEEE, 2012.

[134 Mining Review Africa, "Innovative Vanadium Electrolyte Rental Product for Industrial Use," Mining Review ] Africa, 11 June 2019 (https://www.miningreview.com/energy/innovative-vanadium-electrolyte-rental-productfor-industrial-use/).

[135 J. Spector, "A New Path to Market for Flow Batteries: Rent an Electrolyte," Green Tech Media, 20 February ] 2019 (https://www.greentechmedia.com/articles/read/new-path-to-market-for-flow-batteries-rent-anelectrolyte\#gs.hs5jkf). 
[136 First Solar, "Sustainability Report 2017," First Solar, Tempe, AZ, 2017. ]

[137 C. Reise and B. Farnung, "Uncertainties in PV System Yield Predictions and Assessments," Report IEA] PVPS T13-12, 2017. 

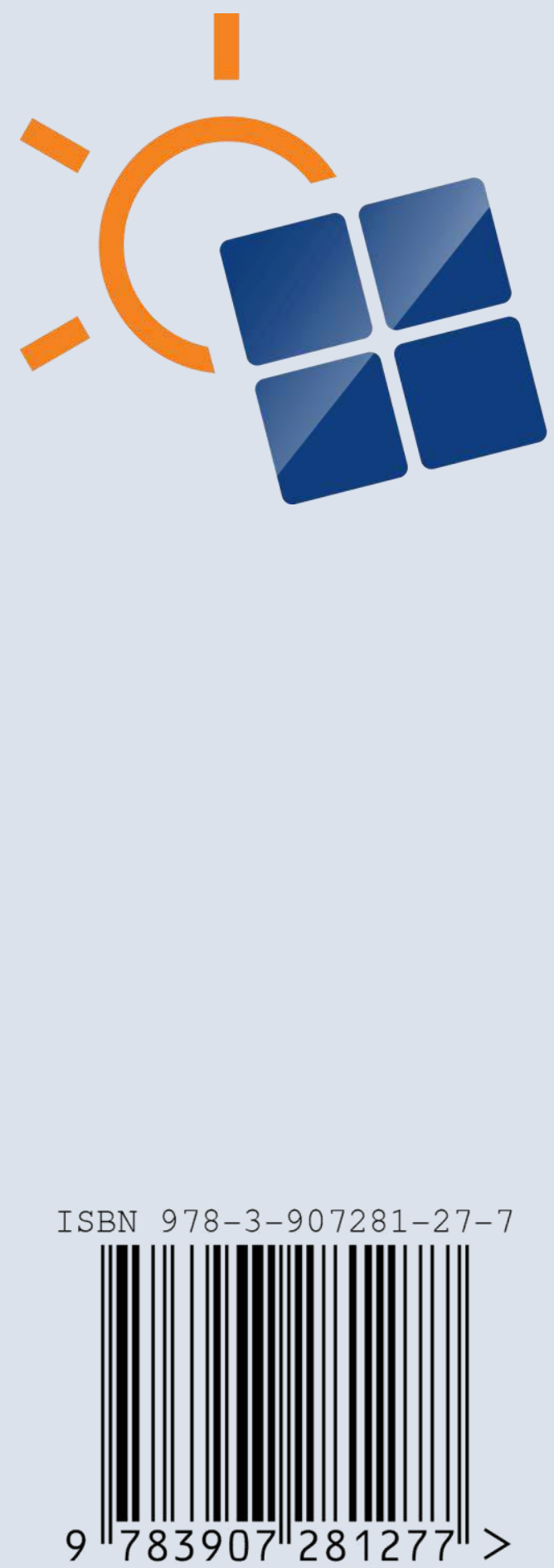